\title{
THERMODYNAMIC AND ENVIRONMENTAL COMPARATIVE INVESTIGATION AND OPTIMIZATION OF LANDFILL VS. INCINERATION FOR MUNICIPAL SOLID WASTE: A CASE STUDY IN VARAMIN, IRAN
}

\author{
Amir Ghasemi $^{1 \star}$, Mehrnoosh Moghaddam ${ }^{1}$
}

\begin{abstract}
Waste to energy (WtE) introduces an appropriate solution for municipal solid waste (MSW) disposal and greenhouse gas emission reduction. In this study, for Varamin MSW management, a gas turbine plant with heat recovery unit that is fed by landfill gas (LFG) and combined heat and power (CHP) incineration plant is investigated and compared as two WtE systems to reveal the best plant effectively. Exergy and environmental analyses of two systems are performed. Moreover, the effects of key parameters as decision variables on the energy and exergy efficiencies are identified by sensitive analysis of both systems. Multi-objective optimization of thermal and exergy efficiencies are then done by using Genetic Algorithm (GA) for each studied system. As a result, Furnace in incineration system and Combustion Chamber in landfill system have the most exergy destruction rate. Also, optimization results show that thermal and exergy effectiveness for landfill system are improved by $7.01 \%$ and $6.53 \%$ respectively; these values for incineration system are calculated to be $45.35 \%$ and $92.75 \%$ respectively.
\end{abstract}

Keywords: Waste to Energy, Exergy, Environmental Analysis, Landfill Plant, Incineration Plant, Multi Objective Optimization

\section{INTRODUCTION}

An evolutionary of the primary and second laws of the thermodynamic was carried out for a $14.25 \mathrm{MW}$ cogeneration system, in Turkey. The energy demand of the patron was around $10.5 \mathrm{MW}$ whereas the cogeneration system generated practically 1.35 times the patron demand. The results illustrated that the highest amount of the irreversibility happened within the boiler, and the economizer and stack had the more important irreversibilities, respectively [1]. The analyses of fundamental laws of thermodynamics were accomplished for a $6.5 \mathrm{MW}$ power plant located in Adana, Turkey. Parts of the system, tested in that study, were classified as a fluidized bed coal combustor, a heat recovery steam generator, an economizer, fans, pumps, a cyclone, and a chimney. All of the parts were assessed and the energy and exergy analyses were investigated for all of the system components [2]. The thermodynamic investigation was fulfilled to indicate the performance of the 14.25 MW cogeneration proposed energy system and the parts of the system were observed and thermodynamic performance assessments were evaluated. The produced results were illustrated that major exergy destruction occurred in the boiler, which was $42 \%$ of the whole system irreversibility. Moreover, the energy efficiencies of the components were calculated [3]. The assessment of a $6.5 \mathrm{MW}$ energy system was performed based on thermodynamic indicators. The energetic and exergetic investigation applied to all of the equipment separately and the primary source of irreversibility and exergy destruction rate was derived. In that survey higher excess air induces the decrease of combustion exergy efficiency in fluidized bed coal combustor. This drawback could be decrement by decreasing the air flow rate in that part of the system [4]. The exergy and exergoeconomic assessment of a biogas engine powered energy system in a wastewater treatment plant located in Turkey were performed to detecting the significant exergy destruction and calculating operating, maintenance, capital investment, the total cost of the system and produced electricity cost. The outputs illustrated that the gas engine and exhaust gas heat exchanger had been had the highest rate of exergy destruction in the proposed system, respectively. Also, the total cost of the system was founded 28.64 US $\$ / h$, and the exergy cost and electricity production cost in the turbine were founded $4.87 \mathrm{US} \$ / \mathrm{h}$ and 11.32 US\$/GJ [5]. Performance analyses of multi-effect desalination coupled to a combined cooling, heating and power energy system were accomplished. The primary goal of that survey was analyzing the thermodynamic performance of an integrated system. EES software was used to the modeling of the system and outputs was indicated that overall efficiency of the integrated system is reached to $84 \%$. Moreover, the parameters that had detected to improve the performance of the system was analyzed [6].

This paper was recommended for publication in revised form by Regional Editor N. Filiz Özdil

${ }^{1}$ School of Engineering, Department of Environment, University of Tehran,

*E-mail address: amir_ghasemi@ut.ac.ir, amir.ghasemi.ut.ir@gmail.com

Orcid id: 0000-0002-3910-6828, 0000-0003-2039-9859

Manuscript Received 05 August 2018, Accepted 15 September 2018 
MSW (Municipal Solid Waste) is considered as a renewable energy source because wastes are continuously produced in the world; hence energy from waste can be a significant way to reduce energy production from non-renewable energy sources such as fossil fuels and GHG (Greenhouse Gas) emissions [7],[8]. The various form of utilization of municipal solid waste in order to energy producing in the developed countries was carried out to indicate the efficient way. The Tokyo that is located in Japan has been considered to a case study to this aim. After assessment of potential scenarios, the best option was selected. In that selected option the energy efficiency will reach $65.95 \%$ in 2030 . Moreover, in that scenario $6.58 \times 105$ tons of $\mathrm{CO}_{2}$ emissions will reduce. the article provided a practical guide for founding a more efficient MSW management system for the purpose of a low carbon society [9]. The analyzing of the exergy efficiency of electricity production of the landfill from a landfill that located in Greece was carried out. The main aim in that survey was clarifying this issue that how the extension of the landfill influence power generation. That potential of every form of extensions was compared, and the results were presented [10]. Advanced exergy and environmental analysis of a steam cycle of a municipal solid waste incineration plant were accomplished to determine the thermodynamic performance of the main parts such as exergy annihilation and energy efficiency. To detecting the potential for improvement in the incineration steam cycle, an advanced energetic assessment was done in four categories. The results illustrated that total plant exergy destruction could be decreased by $8.4 \%$, through improvements in efficiency at plant components considering the best available technologies and operating parameters [11]. Thermodynamic evaluation of a municipal solid waste-to-energy boiler for three case studies in Tehran was conducted, and the main reasons of irreversibility within the boiler was detected. Moreover, the energy and exergy analysis were then accomplished for all components, and the entire boiler and results unmasked that the irreversibility in the furnace, with 52,617.3 $\mathrm{kJ} . \mathrm{s}-1$ was the primary cause of the exergy annihilation. Besides, the overall energetic and exergetic efficiency of the mentioned boiler were calculated as 78.7 and $16.0 \%$, respectively [12].

The waste to energy (WtE) conversion systems are used to convert solid waste into fuels, electric power and heat. They are classified as the thermochemical and the biochemical methods [13]. Waste incineration is most commonly used as the thermo-chemical process. Complete oxidation of organic substances in waste materials occurs during the incineration process [14]. Energy recovery is performed by using the heat content of the combustion products. The temperature of products depends on LHV (Low Heating Value), moisture and ash content of MSW. Minimum range of the solid waste LHV that waste can be burnt without auxiliary fuel is 57GJ/Mg [15]. Energy productions in this process can be only electricity or combined heat and power (CHP); But CHP is found to perform better in life cycle assessment (LCA) and system efficiency evaluation than only electricity production [16]. One of the biochemical processes in waste to energy systems is Biogas produced from organic waste material in the landfill site. It can be used as fuel directly or produce electricity and heat [17]. Recently biogas-based CHP systems are used widely in the world because of these systems use less fuel than separate power and heat systems [18],[19]. In this research, two waste to energy systems: a landfill plant, which is fed by LFG (Landfill Gas), including a gas turbine associated with a heat recovery unit and a CHP incineration plant are investigated from the standpoints of energy, exergy and environmentally based on the Varamin, Iran data in order to designate the best system efficiently and environmentally. For this purpose, the thermodynamic and exergy efficiencies and total GHG emissions are calculated by utilizing mass, energy and exergy balances to each system using EES software [20]. The effects of key thermodynamic parameters on the energy and exergy efficiencies are then identified by system sensitive analysis. Afterward, both systems are optimized to maximize the thermal and exergy efficiencies simultaneously employing genetic algorithm programming using MATLAB software [21].

\section{MATERIALS AND METHODS}

Figure 1 shows the configuration of the designed landfill plant. LFG collected from landfill site is used as fuel in this plant. LFG (i.e., stream 3) and compressed air (i.e., stream 2) enter into the combustion chamber and, so, combustion reaction occurs. Then flue gases (i.e., stream 4) go to the gas turbine (G.T) and produce power. After G.T, stream 5 enters to the heat recovery steam generator (HRSG) and its temperature decreases and then goes through stock. The heat of stream five is used to produce steam in HRSG for increasing system efficiency. Figure 2 exhibits the configuration of studied CHP incineration system. Solid wastes are combusted over a moving grate furnace. Heat from flue gas combustion is used in the boiler to produce superheated steam consequently. Then, the flue gas at $155^{\circ} \mathrm{C}$ goes through the cleaning system and releases to the atmosphere by 
stock. Superheated steam enters steam turbine (S.T) of a Rankine cycle and produces power. Outlet stream of the turbine is condensed to produce saturated water (stream 9) that is pumped to provide the operating pressure of the Rankine cycle. Then stream six goes to the boiler to complete the cycle. For increasing system efficiency, the heat of stream eight is used to generate domestic hot water (i.e., stream 11) by heat recovery from the condenser component.

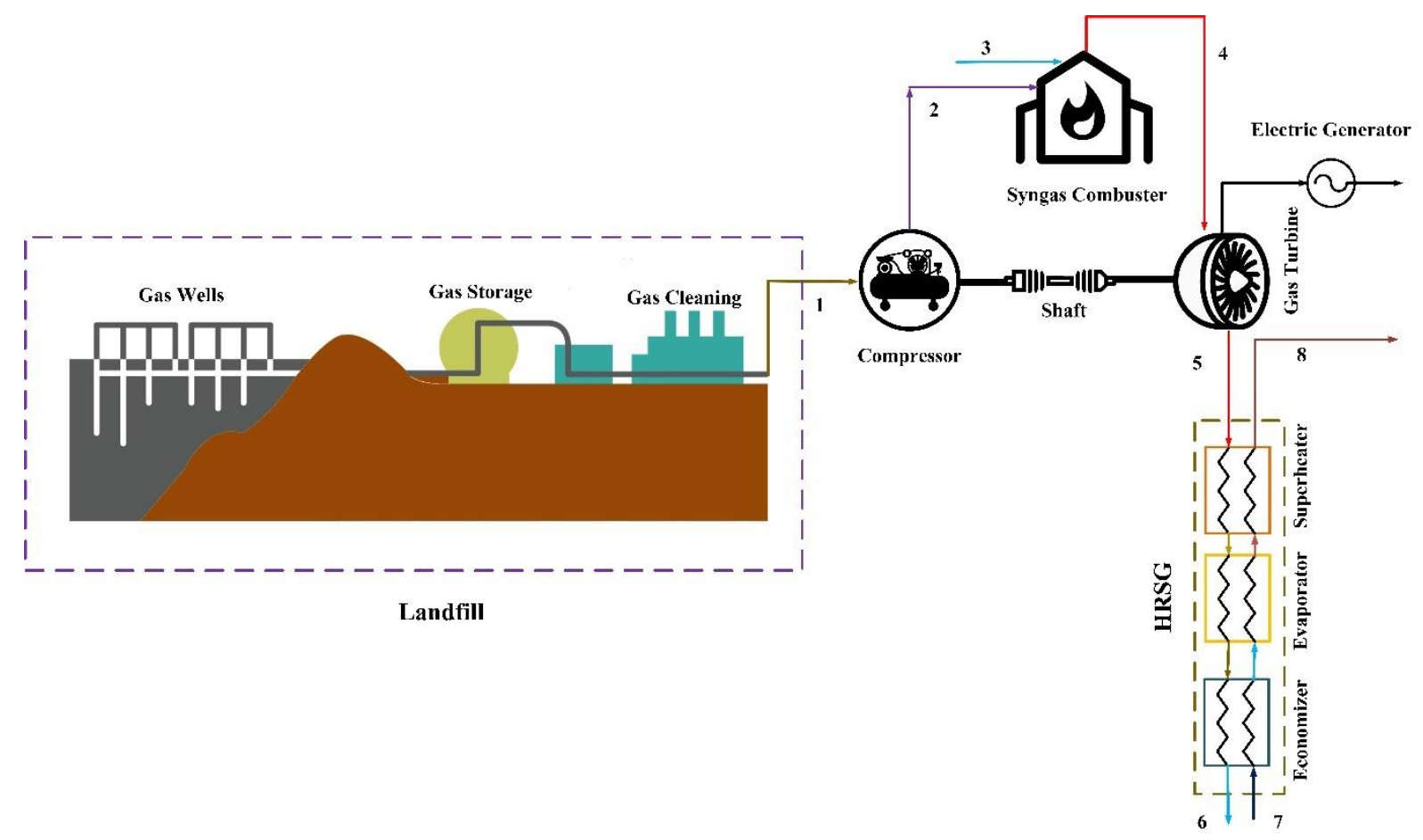

Figure 1. Landfill plant configuration

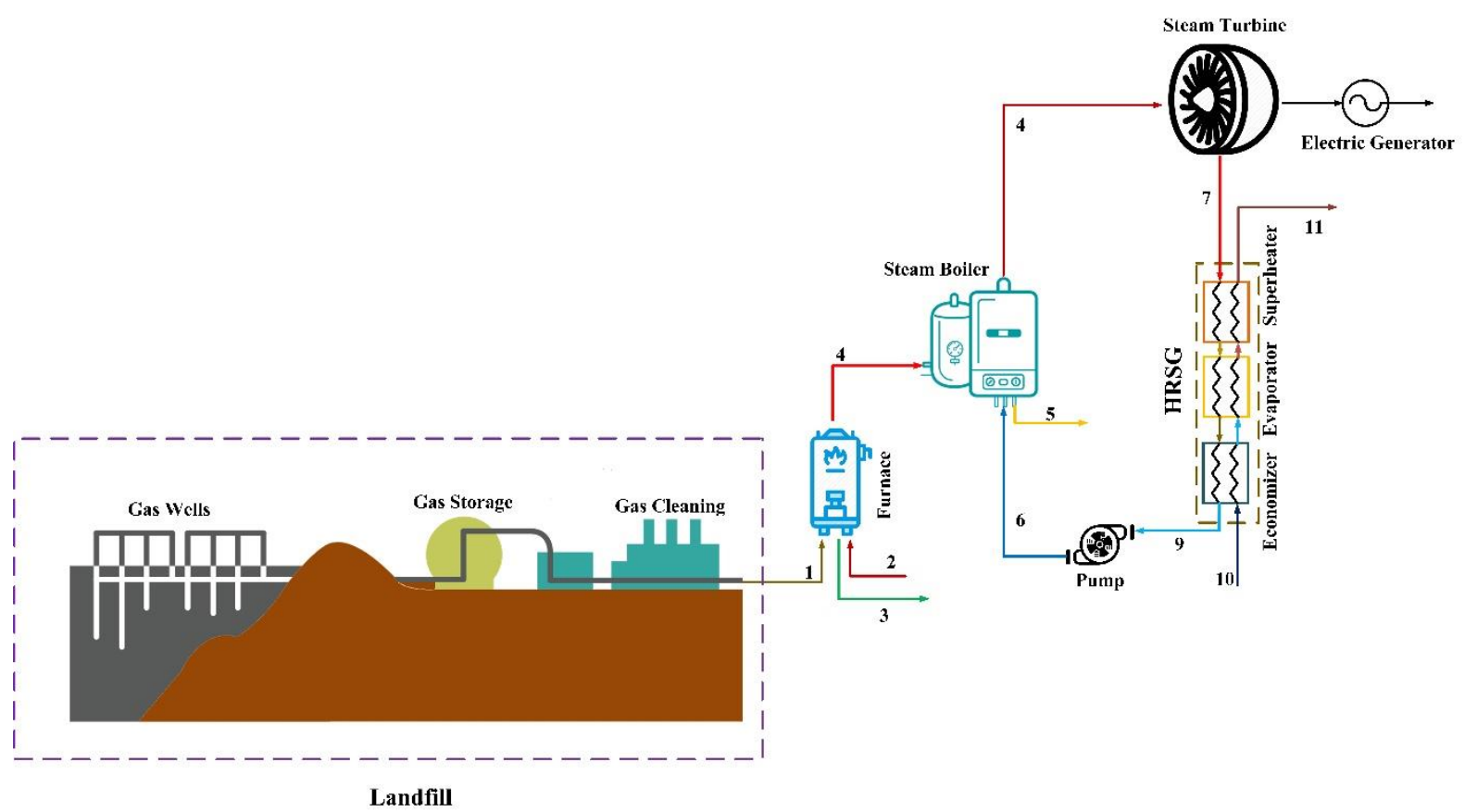

Figure 2. Incineration plant configuration 
The thermodynamic modeling of the proposed WtE systems is described in this section. The thermodynamic properties and exergy of the streams are calculated by solving energy and exergy balances via the EES software. The following assumptions are considered for oversimplification of theoretical analysis of the systems:

- The process is considered to be steady state.

- The pressure drops in all pipes are neglected.

- Changes in potential and kinetic exergies are neglected.

- Adiabatic situation and equations are assumed to turbines and heat exchangers in this paper

- Heat loss from furnace incineration is assumed to be 5\% of the MSW low heating value [22].

- Air and combustion products are considered to be ideal gasses.

For the energy analysis of the system, the conservation laws of mass and energy are applied to each component of the framework. Each component of the system can be considered as a control volume. For a component with inlet $\mathrm{i}$ and outlet $\mathrm{o}$, mass and energy conversations can be written as below [23]:

$$
\begin{gathered}
\sum \dot{m}_{i}=\sum \dot{m}_{o} \\
\sum \dot{Q}_{t o t}-\sum \dot{W}_{t o t}=\sum \dot{m}_{o} h_{o}-\sum \dot{m}_{i} h_{i}
\end{gathered}
$$

Energy efficiency of the landfill cycle is formulated as follows:

$$
\eta_{l f, C H P}=\frac{\dot{W}_{N e t, l f}+\dot{W}_{S, l f}}{L H V_{m t h n} \times \dot{m}_{f, m t h n}}
$$

In the above expression, the terms $\dot{\mathrm{W}}_{\mathrm{Net}, \mathrm{ff}}$ and $\dot{\mathrm{W}}_{\mathrm{S}, \mathrm{f}}$ express pure power and steam produced in the landfill cycle respectively. On the other side, the energy efficiency of the incineration cycle is performed as follows:

$$
\eta_{i n c, C H P}=\frac{\dot{W}_{N e t, i n c}+\dot{W}_{H W, i n c}}{L H V_{s w} \times \dot{m}_{f, s w}}
$$

Where, the terms $\dot{\mathrm{W}}_{\mathrm{Net}, \text { inc }}$ and $\dot{\mathrm{W}}_{\mathrm{HW} \text {,inc }}$ state the net power and hot water produced by the incineration cycle respectively. The maximum work that can be observed from a given form of energy that is utilizing the environmental parameters as the reference state is introduced as exergy [24]. On the other hand, exergy is an attribute of the system and environment together. The exergy rate $(\dot{X})$ of a process stream, in the absence of electrical and magnetic effects, is separated into four terms. Two of them are physical exergy $\left(\dot{\mathrm{X}}_{\mathrm{PH}}\right)$ and chemical exergy $\left(\dot{\mathrm{X}}_{\mathrm{CH}}\right)$ which are defined as follows [25]:

$$
\dot{X}_{P H}=\dot{m} \times\left[\left(h-h_{0}\right)-T_{0} \times\left(s-s_{0}\right)\right]
$$


Journal of Thermal Engineering, Research Article, Vol. 6, No. 6, Special Issue 12, pp. 226-246, December, 2020

$$
\dot{X}_{C H}=\sum_{j=1}^{n} y_{j} \times \dot{X}_{C H, j}+R \times T_{0} \times \sum_{j=1}^{n} y_{j} \times \ln \left(y_{j}\right)
$$

Physical exergy is the highest beneficial work available as a system interplays with an equilibrium state. Chemical exergy is dependent on the chemical composition of the process stream (including the mixture or pure) at its state and when it reaches in an equilibrium state with the reference environment [26]. The two other terms, kinetic exergy rate $\left(\dot{\mathrm{X}}_{\mathrm{KN}}\right)$ and potential exergy rate $\left(\dot{\mathrm{X}}_{\mathrm{PT}}\right)$, are considered to be negligible as movements are relatively low, and elevation changes are small [27]. Applying the first and the second laws of thermodynamics to the system components, the exergy balance is achieved as follows [28]:

$$
\begin{gathered}
\dot{\mathrm{X}}_{\mathrm{Q}}+\sum_{\mathrm{i}} \dot{\mathrm{m}}_{\mathrm{i}} \mathrm{x}_{\mathrm{i}}=\sum_{\mathrm{o}} \dot{\mathrm{m}}_{\mathrm{o}} \mathrm{x}_{\mathrm{o}}+\dot{\mathrm{X}}_{\mathrm{W}}+\dot{\mathrm{X}}_{\mathrm{D}} \\
\dot{X}_{Q}=\left(1-\frac{T_{0}}{T}\right) Q \\
\dot{X}_{W}=\dot{W}
\end{gathered}
$$

Where $\dot{X}_{\mathrm{Q}}$ and $\dot{\mathrm{X}}_{\mathrm{W}}$ determine exergies of the heat transfer and the work which across the boundaries of the control volume. Also, the Dead State situations are considered as $\mathrm{T}_{0}=298 \mathrm{~K}$ and $\mathrm{P}_{0}=1$ bar for the both proposed systems. The feed exergy $\left(\dot{\mathrm{X}}_{\mathrm{F}, \mathrm{k}}\right)$ and product exergy $\left(\dot{\mathrm{X}}_{\mathrm{P}, \mathrm{k}}\right)$ of each component in the system is obtained based on the exergy calculated for each inlet/outlet stream of that component. The feed exergy is the required exergy to generate the product of a specified element, and the product exergy is what we desire from a part, regarding exergy [29]. The feed and product exergies for each element of the system are presented in Table 1 and Table 2 for landfill and incineration systems respectively.

Table 1. Feed exergy and product exergy for each component of the proposed landfill system

\begin{tabular}{|c|c|c|}
\hline Component & Feed exergy $\left(\dot{\mathrm{X}}_{\mathrm{F}, \mathrm{k}}\right)$ & Product exergy $\left(\dot{\mathrm{X}}_{\mathrm{P}, \mathrm{k}}\right)$ \\
\hline A.C & $\dot{\mathrm{X}}_{\mathrm{F}, \mathrm{A} . \mathrm{C}}=\dot{\mathrm{W}}_{\mathrm{A} . \mathrm{C}}$ & $\dot{\mathrm{X}}_{\mathrm{P} \text { A.C }}=\dot{\mathrm{X}}_{2}-\dot{\mathrm{X}}_{1}$ \\
\hline C.C & $\dot{\mathrm{X}}_{\mathrm{F}, \mathrm{C} . \mathrm{C}}=\dot{\mathrm{X}}_{2}+\dot{\mathrm{X}}_{3}$ & $\dot{\mathrm{X}}_{\mathrm{P}, \mathrm{C} \mathrm{C}}=\dot{\mathrm{X}}_{4}$ \\
\hline G.T & $\dot{\mathrm{X}}_{\mathrm{F}, \mathrm{G} . \mathrm{T}}=\dot{\mathrm{X}}_{4}-\dot{\mathrm{X}}_{5}$ & $\dot{\mathrm{X}}_{\mathrm{P}, \mathrm{G} \mathrm{T}}=\dot{\mathrm{W}}_{\mathrm{G} . \mathrm{T}}$ \\
\hline HRSG & $\dot{\mathrm{X}}_{\mathrm{F}, \mathrm{HRSG}}=\dot{\mathrm{X}}_{5}-\dot{\mathrm{X}}_{6}$ & $\dot{\mathrm{X}}_{\mathrm{P}, \mathrm{HRSG}}=\dot{\mathrm{X}}_{8}-\dot{\mathrm{X}}_{7}$ \\
\hline
\end{tabular}

Table 2. Feed exergy and product exergy for each component of the proposed incineration system

\begin{tabular}{|c|c|c|}
\hline Component & Feed exergy $\left(\dot{\mathrm{X}}_{\mathrm{F}, \mathrm{k}}\right)$ & Product exergy $\left(\dot{\mathrm{X}}_{\mathrm{P}, \mathrm{k}}\right)$ \\
\hline Frnc & $\dot{\mathrm{X}}_{\mathrm{F}, \mathrm{Frnc}}=\dot{\mathrm{X}}_{1}+\dot{\mathrm{X}}_{2}$ & $\dot{\mathrm{X}}_{\mathrm{P}, \mathrm{Frnc}}=\dot{\mathrm{X}}_{3}+\dot{\mathrm{X}}_{4}$ \\
\hline Blr & $\dot{\mathrm{X}}_{\mathrm{P}, \mathrm{Blr}}=\dot{\mathrm{X}}_{4}-\dot{\mathrm{X}}_{5}$ & $\dot{\mathrm{X}}_{\mathrm{P}, \mathrm{Blr}}=\dot{\mathrm{X}}_{7}-\dot{\mathrm{X}}_{6}$ \\
\hline S.T & $\dot{\mathrm{X}}_{\mathrm{F}, \mathrm{S} \mathrm{T}}=\dot{\mathrm{X}}_{7}-\dot{\mathrm{X}}_{8}$ & $\dot{\mathrm{X}}_{\mathrm{P}, \mathrm{S} \mathrm{T}}=\dot{\mathrm{W}}_{\mathrm{S} . \mathrm{T}}$ \\
\hline Cond & $\dot{\mathrm{X}}_{\mathrm{F}, \text { Cond }}=\dot{\mathrm{X}}_{8}-\dot{\mathrm{X}}_{9}$ & $\dot{\mathrm{X}}_{\mathrm{P} \text { Cond }}=\dot{\mathrm{X}}_{11}-\dot{\mathrm{X}}_{10}$ \\
\hline Pump & $\dot{\mathrm{X}}_{\mathrm{F}, \text { Pump }}=\dot{\mathrm{W}}_{\mathrm{Pump}}$ & $\dot{\mathrm{X}}_{\mathrm{Pump}}=\dot{\mathrm{X}}_{6}-\dot{\mathrm{X}}_{9}$ \\
\hline
\end{tabular}


The difference between feed and product exergies of a component reveals the amount of exergy destructed by that component which is described by the exergy destruction rate parameter $\left(\dot{X}_{D, k}\right)$ as defined by below expression [30]:

$$
\dot{X}_{D, k}=\dot{X}_{F, k}-\dot{X}_{P, k}
$$

The exergy efficiency parameter $\left(\varepsilon_{k}\right)$ is defined as the percentage of the feed exergy procured to the system which is found in the product exergy [31]. So, the corresponding equation is expressed as [32]:

$$
\varepsilon_{k}=\frac{\dot{X}_{P, k}}{\dot{X}_{F, k}}
$$

Also, the exergy destruction ratio parameter $\left(\dot{\mathrm{X}}_{\mathrm{P}, \mathrm{k}}\right)$ is calculated to understand which component of the system has the most adverse impact on the system and is determined by the following expression [33]:

$$
y_{D, k}=\frac{\dot{X}_{D, k}}{\dot{X}_{F, t o t}}
$$

Where the $\dot{\mathrm{X}}_{\mathrm{P}, \mathrm{k}}$ is the feed exergy provided to the whole system, and it is equal to $\dot{\mathrm{X}}_{3}$ for the landfill system and $\dot{X}_{1}$ for the incineration system based on Figure 1 and 2.

Finally, the exergy efficiency of proposed landfill system can be written as:

$$
\varepsilon_{l f}=\frac{\dot{X}_{N e t, l f}+\dot{X}_{S, l f}}{\dot{X}_{f, m t h n}}
$$

And that for the proposed incineration system will be equal to:

$$
\varepsilon_{i n c}=\frac{\dot{X}_{N e t, i n c}+\dot{X}_{H W, i n c}}{\dot{X}_{f, s w}}
$$

GHG emissions are studied to investigate and compare the environmental effects of both processes. Figure 3 shows the emissions structures of landfill and incineration systems. This figure illustrates the considered MSW management scenarios and prediction of the consequences of them. The forms of emissions are different, as it is clear in figure 3, the more useful ways to manage MSW are energy recovery from landfill and incineration systems because of the avoidance potential of the greenhouse gas emissions. GHG emissions are estimated for both operations by Equation 15 and 16 [34],[35]

$$
G H G_{L F}=G H G_{L F G}+G H G_{S, L F}-G H G_{E R, L F}
$$

Where $\mathrm{GHG}_{\mathrm{LF}}, \mathrm{GHG}_{\mathrm{LFG}}, \mathrm{GHG}_{\mathrm{S}, \mathrm{LF}}$ and $\mathrm{GHG}_{\mathrm{ER}, \mathrm{LF}}$ are net GHG emissions from landfill, GHG emissions from landfill $\mathrm{CH}_{4}$, GHG emissions from stack release system and GHG depletions from electricity and heat in landfill respectively. Energy recovery from the landfill can contribute to decreasing fossil fuel resources usage [26].The production of electricity and heat in the landfill system are compared with the electricity and heat emission factor in Iran's gas turbine power plants that are fed by natural gas. The electricity and heat emissions factors are $0.782 \mathrm{~kg} \mathrm{CO} 2 \mathrm{e}$ per $\mathrm{kWh}$ and $0.0624 \mathrm{~g} \mathrm{CO} 2 \mathrm{e}$ per $\mathrm{kJ}$, respectively [34].

$$
G H G_{I N C}=G H G_{S, I N C}-G H G_{E R, I N C}
$$


Where $\mathrm{GHG}_{\mathrm{INC}}, \mathrm{GHG}_{\mathrm{S}, \mathrm{INC}}$ and $\mathrm{GHG}_{\mathrm{ER}, \mathrm{INC}}$ are net $\mathrm{GHG}$ emissions from incineration, GHG emissions from stack discharge system and GHG depletions from electricity and heat in incineration respectively. The energy from MSW incineration system, like the landfill system, reduces energy production from fossil fuel resources [26]. The electricity and heat emission factor in Iran's steam power plants fed by natural gas is $0.633 \mathrm{~kg} \mathrm{CO} e$ per $\mathrm{kWh}$ and $0.0624 \mathrm{~g} \mathrm{CO} 2 \mathrm{e}$ per $\mathrm{kJ}[36]$.

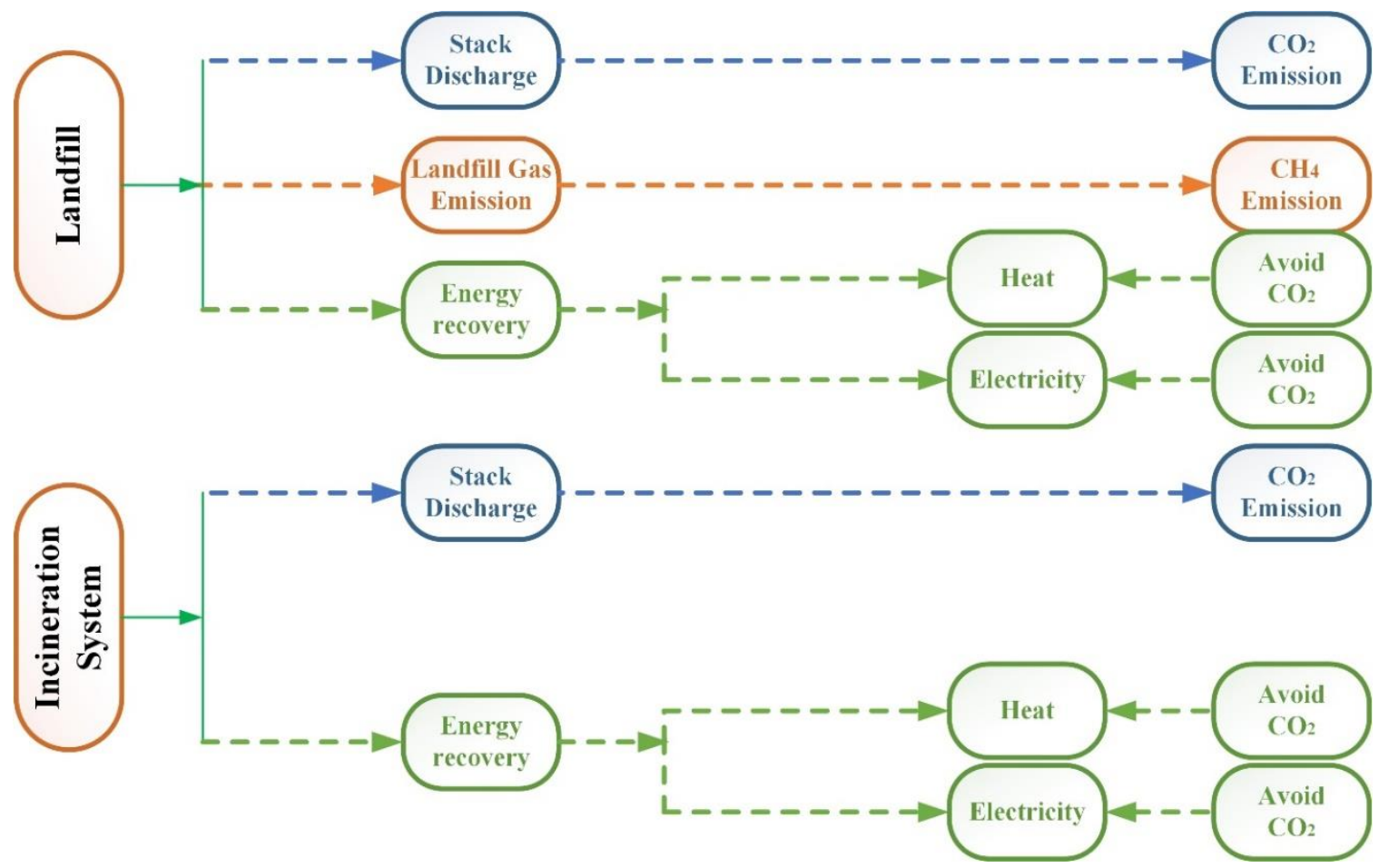

Figure 3. Emissions' structures of landfill and incineration systems

\section{RESULT AND DISCUSION}

As the proposed WtE systems are designed to be used in the Varamin city region, it is needed to determine the specification of fuel for each system according to Varamin city conditions. The flow rate of MSW is considered to be 200 tons/day based on the Varamin daily MSW production, and its chemical composition is obtained experimentally, and the results are described in Table 3 .

Table 3. Chemical analysis of Varamin city MSW [37].

\begin{tabular}{|c|c|}
\hline Component & \% Wt \\
\hline C & 13.67 \\
\hline H & 1.92 \\
\hline O & 11.5 \\
\hline N & 0.78 \\
\hline S & 0.13 \\
\hline Ash & 20 \\
\hline H2O & 52 \\
\hline
\end{tabular}

LFG emissions rate in the landfill must be calculated for design landfill CHP plant. Figure 4 illustrates methane, $\mathrm{CO}_{2}$ and total LFG yearly mass rate emissions based on Land GEM model and its input parameters are considered $\mathrm{k}=0.05$ year- $1, \mathrm{~L} 0=173.4 \mathrm{~m} 3 / \mathrm{Mg}$, and methane content volume equals to $60 \%$. $\mathrm{LFG}$ rate that is fed to landfill energy system recovery is deemed to be constant equals to 5438.53 tons per year (emissions in 2019). Therefore, the results of the thermodynamic analysis (energy and exergy) of both systems are performed by Table 5 and Table 6 for landfill and incineration systems respectively, using input data shown in Table 4. 
Journal of Thermal Engineering, Research Article, Vol. 6, No. 6, Special Issue 12, pp. 226-246, December, 2020

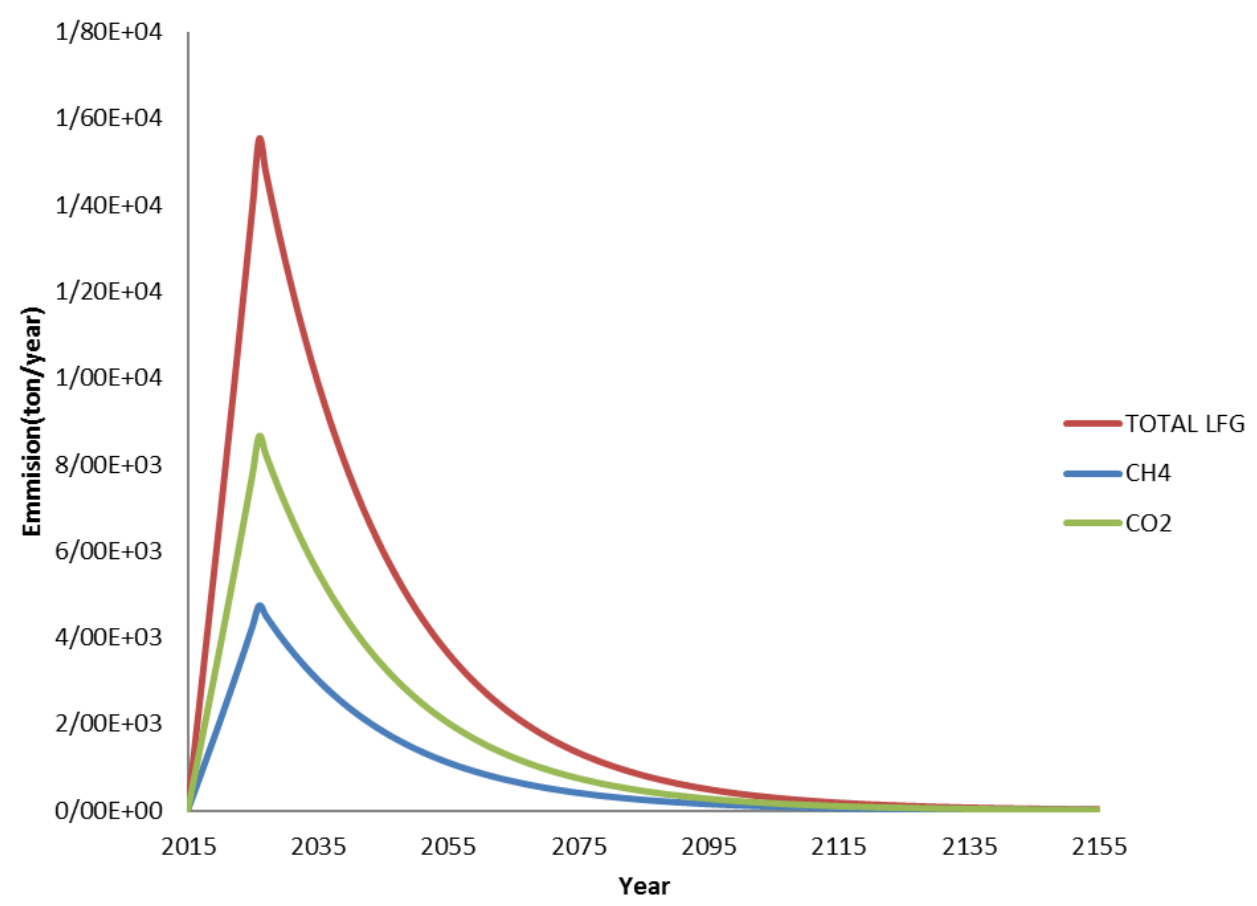

Figure 4. LFG emissions rate in landfill

Table 4. Input data for both proposed systems

\begin{tabular}{|l|c|}
\hline \multicolumn{1}{|c|}{ Parameter \& Unit } & Value \\
\hline \multicolumn{2}{|c|}{ Landfill system } \\
\hline Dead state temperature $\left({ }^{\circ} \mathrm{C}\right)$ & 25 \\
\hline Dead state pressure $(\mathrm{kPa})$ & 100 \\
\hline LFG inlet temperature $\left({ }^{\circ} \mathrm{C}\right)$ & 25 \\
\hline LFG inlet pressure $(\mathrm{kPa})$ & 600 \\
\hline Compressor pressure ratio $(-)$ & 6 \\
\hline Turbine back pressure $(\mathrm{kPa})$ & 100 \\
\hline Low heat value of fuel $(\mathrm{kJ} / \mathrm{kg})$ & 17685.5 \\
\hline Turbine isentropic efficiency $(\%)$ & 92 \\
\hline Compressor isentropic efficiency $(\%)$ & 90 \\
\hline HRSG water inlet pressure $(\mathrm{kPa})$ & 100 \\
\hline HRSG water inlet temperature $\left({ }^{\circ} \mathrm{C}\right)$ & 25 \\
\hline & \\
\hline Dead state temperature $\left({ }^{\circ} \mathrm{C}\right)$ & 25 \\
\hline Dead state pressure $(\mathrm{kPa})$ & 100 \\
\hline Turbine inlet temperature $\left({ }^{\circ} \mathrm{C}\right)$ & 280 \\
\hline Turbine inlet pressure $(\mathrm{kPa})$ & 3200 \\
\hline Turbine back pressure $(\mathrm{kPa})$ & 10 \\
\hline Turbine isentropic efficiency $(\%)$ & 85 \\
\hline Pump isentropic efficiency $(\%)$ & 83 \\
\hline flue gas outlet temperature $(\mathrm{C})$ & 155 \\
\hline Low heat value of fuel $(\mathrm{kJ} / \mathrm{kg})$ & 5247 \\
\hline Cond water inlet pressure( $(\mathrm{kPa})$ & 100 \\
\hline Cond water inlet temperature $\left({ }^{\circ} \mathrm{C}\right)$ & 25 \\
\hline
\end{tabular}


Journal of Thermal Engineering, Research Article, Vol. 6, No. 6, Special Issue 12, pp. 226-246, December, 2020

Table 5. Process streams output data (landfill system)

\begin{tabular}{|c|c|c|c|c|c|c|c|}
\hline State & Substance & $\begin{array}{c}\text { Temperature } \\
\left({ }^{\mathbf{C}} \mathbf{C}\right)\end{array}$ & $\begin{array}{c}\text { Pressure } \\
\mathbf{( k P a})\end{array}$ & $\begin{array}{c}\text { Mass flow } \\
(\mathbf{k g} / \mathbf{s})\end{array}$ & $\begin{array}{c}\text { Physical } \\
\text { Exergy }(\mathbf{M W})\end{array}$ & $\begin{array}{c}\text { Chemical } \\
\text { Exergy } \\
(\mathbf{M W})\end{array}$ & $\begin{array}{c}\text { Total Exergy } \\
(\mathbf{M W})\end{array}$ \\
\hline 1 & air & 25 & 101.325 & 2.143 & 0 & 0 & 0 \\
\hline 2 & air & 234.34 & 607.95 & 2.143 & 0.442 & 0 & 0.442 \\
\hline 3 & LFG & 25 & 607.95 & 0.1723 & -0.186 & 3.184 & 2.998 \\
\hline 4 & $\begin{array}{c}\text { combustion } \\
\text { products }\end{array}$ & 1279.53 & 607.95 & 2.3150 & 2.542 & 0.114 & 2.656 \\
\hline 5 & $\begin{array}{c}\text { combustion } \\
\text { products }\end{array}$ & 807.48 & 101.325 & 2.3150 & 1.091 & 0.114 & 1.205 \\
\hline 6 & $\begin{array}{c}\text { combustion } \\
\text { products }\end{array}$ & 300 & 101.325 & 2.3150 & 0.213 & 0.114 & 0.328 \\
\hline 7 & water & 25 & 101.325 & 0.485 & 0 & 0.001 & 0.001 \\
\hline 8 & steam & 197.466 & 101.325 & 0.485 & 0.277 & 0.001 & 0.278 \\
\hline
\end{tabular}

Table 6. Process streams output data (incineration system)

\begin{tabular}{|c|c|c|c|c|c|c|c|}
\hline State & Substance & $\begin{array}{c}\text { Temperature } \\
\left({ }^{\circ} \mathbf{C}\right)\end{array}$ & $\begin{array}{c}\text { Pressure } \\
\mathbf{( k P a )}\end{array}$ & $\begin{array}{c}\text { Mass flow } \\
(\mathbf{k g} / \mathbf{s})\end{array}$ & $\begin{array}{c}\text { Physical } \\
\text { Exergy }(\mathbf{M W})\end{array}$ & $\begin{array}{c}\text { Chemical } \\
\text { Exergy } \\
(\mathbf{M W})\end{array}$ & $\begin{array}{c}\text { Total Exergy } \\
(\mathbf{M W})\end{array}$ \\
\hline 1 & MSW & 25 & 100 & 2.315 & 0 & 19.12 & 19.12 \\
\hline 2 & Air & 25 & 100 & 5.996 & 0 & 0 & 0 \\
\hline 3 & Ash & 100 & 100 & 0.463 & 0.06512 & 0 & 0.06512 \\
\hline 4 & $\begin{array}{c}\text { combustion } \\
\text { products }\end{array}$ & 897.85 & 100 & 7.511 & 5.0636 & 0.0903 & 5.1539 \\
\hline 5 & $\begin{array}{c}\text { combustion } \\
\text { products }\end{array}$ & 155 & 100 & 7.511 & 0.5646 & 0.0903 & 0.6549 \\
\hline 6 & water & 48.97 & 3200 & 2.46 & 0.0079 & 0.0062 & 0.0141 \\
\hline 7 & water & 236.9 & 3200 & 2.46 & 2.5141 & 0.0062 & 2.5203 \\
\hline 8 & water & 45.8317 & 10 & 2.46 & 0.3730 & 0.0062 & 0.3792 \\
\hline 9 & water & 48.2575 & 10 & 2.46 & -0.0006 & 0.0062 & 0.0055 \\
\hline 10 & water & 25 & 100 & 40 & -0.0102 & 0.0458 & 0.0356 \\
\hline 11 & water & 47 & 100 & 40 & 0.3051 & 0.0458 & 0.3508 \\
\hline
\end{tabular}

Table 7. Thermodynamic performance of the studied systems

\begin{tabular}{|c|c|c|}
\hline Parameter & Value & Unit \\
\hline \multicolumn{3}{|c|}{ Landfill system } \\
\hline Total energy input to the system & 3.047 & MW \\
\hline Total exergy input to the system & 3.183 & MW \\
\hline Fuel consumption & 0.172 & $\mathrm{~kg} / \mathrm{s}$ \\
\hline Net electric power generated & 946 & $\mathrm{~kW}$ \\
\hline Mass flow rate of produced steam & 0.485 & $\mathrm{~kg} / \mathrm{s}$ \\
\hline Total energy efficiency & 76.7 & $\%$ \\
\hline Total exergy efficiency & 73.4 & $\%$ \\
\hline \multicolumn{3}{|c|}{ Incineration system } \\
\hline Total energy input to the system & 12.1 & MW \\
\hline Total exergy input to the system & 19.12 & MW \\
\hline Fuel consumption & 2.314 & $\mathrm{~kg} / \mathrm{s}$ \\
\hline Net electric power generated & 1824 & $\mathrm{~kW}$ \\
\hline Mass flow rate of produced hot water & 40 & $\mathrm{~kg} / \mathrm{s}$ \\
\hline Total energy efficiency & 56 & $\%$ \\
\hline Total exergy efficiency' & 35.34 & $\%$ \\
\hline
\end{tabular}


Table 8 and Table 9 based on Table 1 and Table 2 given in the previous section, present the essential exergetic parameters for each component of landfill and incineration systems respectively. According to the Table 5 and 6, the performance of the both studied systems is determined which is described in Table 7.

Table 8. The results of exergy analysis for each component of landfill system

\begin{tabular}{|c|c|c|c|c|}
\hline Component & $\begin{array}{c}\text { Feed exergy } \\
\text { (MW) }\end{array}$ & $\begin{array}{c}\text { Product exergy } \\
\text { (MW) }\end{array}$ & $\begin{array}{c}\text { Exergy destruction } \\
\text { (MW) }\end{array}$ & Exergetic efficiency (\%) \\
\hline A.C & 0.470 & 0.442 & 0.028 & 94 \\
\hline C.C & 3.439 & 2.656 & 0.784 & 77.219 \\
\hline G.T & 1.451 & 1.416 & 0.035 & 97.605 \\
\hline HRSG & 0.878 & 0.277 & 0.601 & 31.536 \\
\hline
\end{tabular}

Table 9. The results of exergy analysis for each component of incineration system

\begin{tabular}{|c|c|c|c|c|}
\hline Component & $\begin{array}{c}\text { Feed exergy } \\
\text { (MW) }\end{array}$ & $\begin{array}{c}\text { Product exergy } \\
\text { (MW) }\end{array}$ & $\begin{array}{c}\text { Exergy destruction } \\
\text { (MW) }\end{array}$ & Exergetic efficiency (\%) \\
\hline Frnc & 19.120 & 5.219 & 13.901 & 27.296 \\
\hline Blr & 4.499 & 2.141 & 2.358 & 47.590 \\
\hline S.T & 2.141 & 1.877 & 0.264 & 87.666 \\
\hline Cond & 0.374 & 0.126 & 0.248 & 33.686 \\
\hline Pump & 0.009 & 0.009 & 0.001 & 94.019 \\
\hline
\end{tabular}

As it is shown in Table 8 for the landfill system, the G.T and A.C have the highest exergy efficiency in comparison to other components due to their low exergy annihilation. Based on this table, $75 \%$ of the whole parts have exergetic efficiencies above $50 \%$, and the HRSG component has the worst exergetic efficiency which equals to $31.5 \%$, so a redesign consideration is needed for this component.

According to Table 9 for the proposed incineration system, Pump and S.T components have the highest exergetic efficiency respectively in the order and $60 \%$ of the cycle's parts have an exergetic efficiency below $50 \%$. The lowest value of exergy efficiency is related to the furnace component, Frnc, in the system due to its highest value of exergy destruction, $13.9 \mathrm{MW}$. The combustion reaction in this component results in a high amount of irreversibilities and, so, the high amount of exergy destruction rate. For a comparison between different components of the landfill system, the values of exergy destruction ratio are performed by Figure 5 As it is seen in this figure, C.C and HRSG have the significant rule in destructing the total exergy input to the system (about $96 \%$ is destructed by these components). Irreversibility in heat exchanger (HRSG) occurs because of transferring heat through finite temperature difference. The significant quantity of entropy is produced in the combustion chamber (C.C) due to combustion and, so, resulting in a significant amount of annihilation.

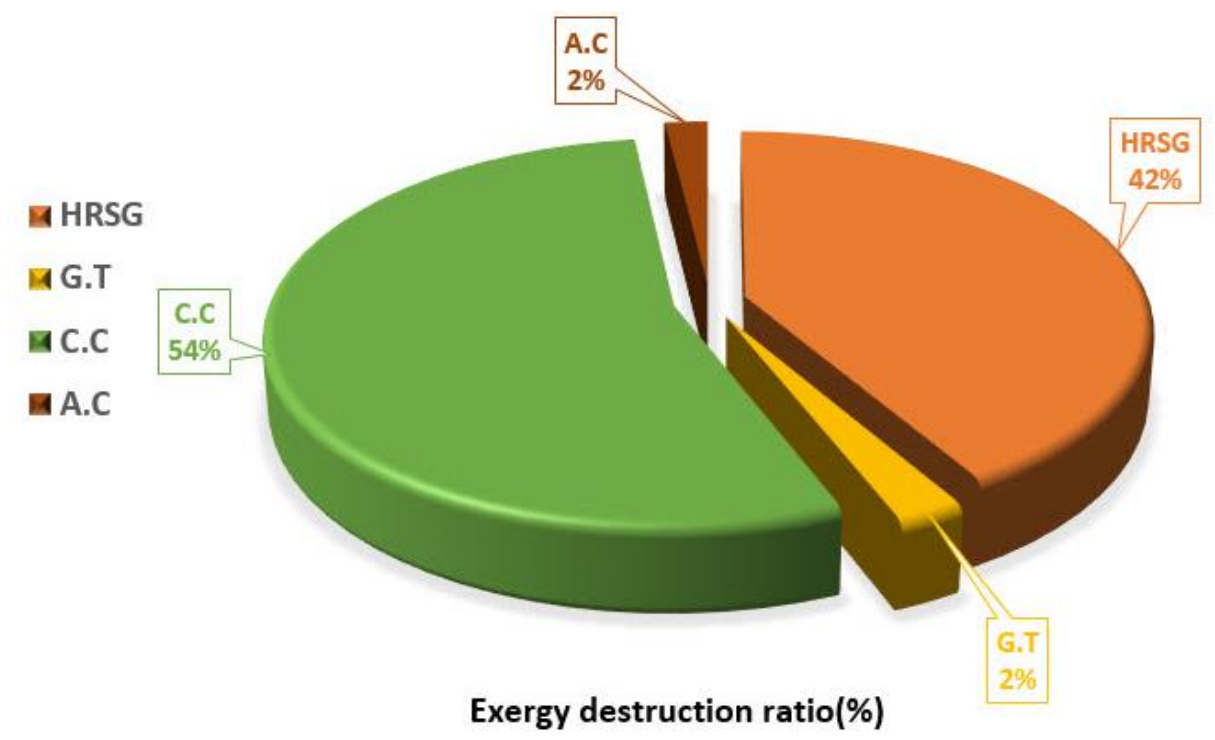

Figure 5. Exergy destruction ratio for various components of the landfill system 
Figure 6 shows the exergy destruction ratio of various components for the incineration system. The exergy destruction ratio value is the most for the French among the other ingredients (83\% approximately). The main reason of irreversibility in the furnace, Frnc, component is related to the chemical reaction; Therefore, a notable reduction in exergy destruction cannot be expected. Still reducing the air-fuel ratio and preheating the combustion air are proposals for improving the performance of the mentioned component. Also, it is realized from this figure that the Pump component has the lowest value of exergy destruction ratio in the system because of its small consumed power.

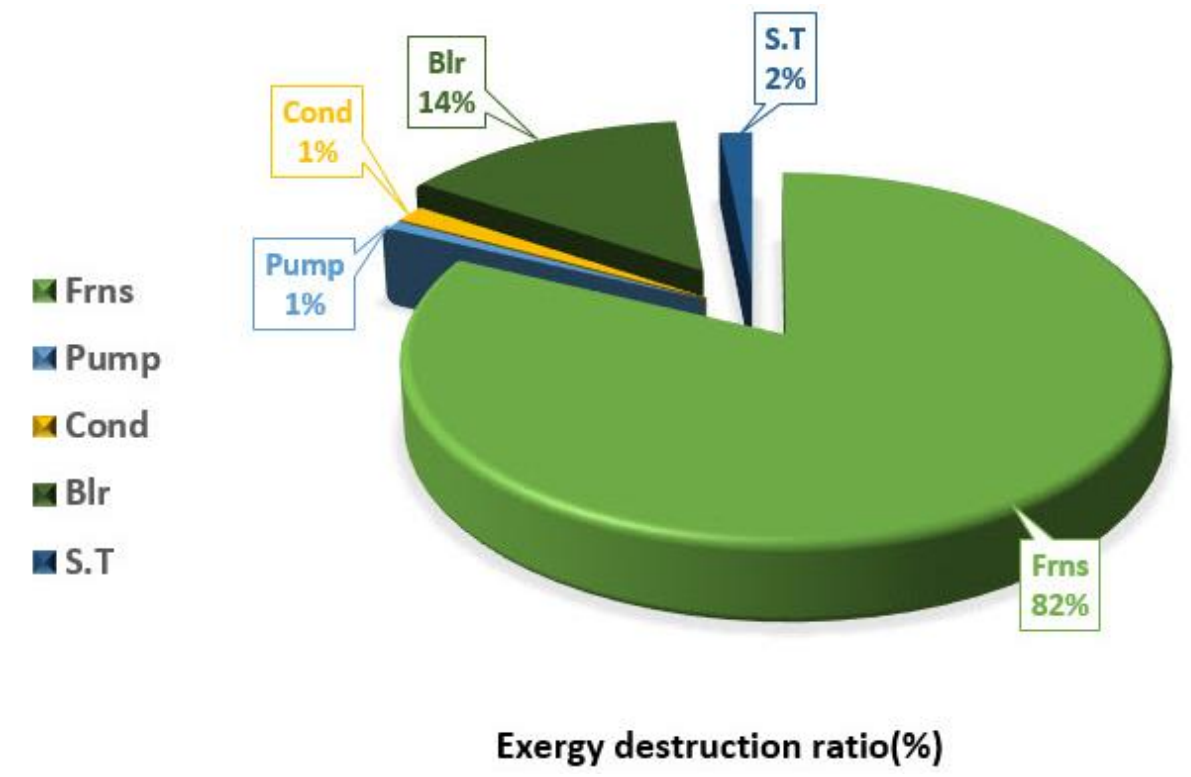

Figure 6. Exergy destruction ratio for components of the incineration system

GHG emissions of landfill and incineration systems are illustrated in Figure 7 and 8 according to Equations 15 and 16. Results show that the landfill system emits $174.2 \mathrm{~kg} \mathrm{CO}$ e.ton-1 MSW while incineration system emits $308 \mathrm{~kg}$ CO2e.ton-1 MSW. Energy recovery from these systems had a vital influence to decrease GHG emissions.

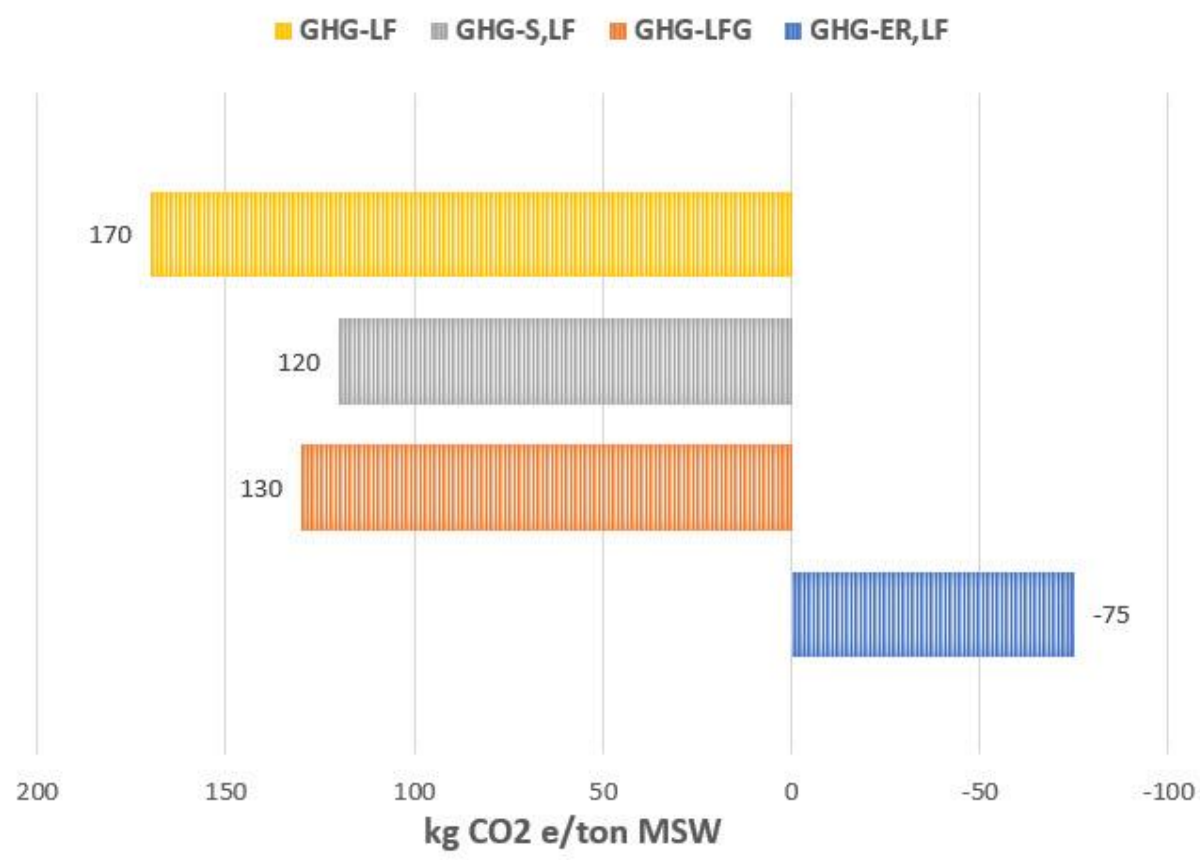

Figure7. GHG emissions from landfill system 
Journal of Thermal Engineering, Research Article, Vol. 6, No. 6, Special Issue 12, pp. 226-246, December, 2020

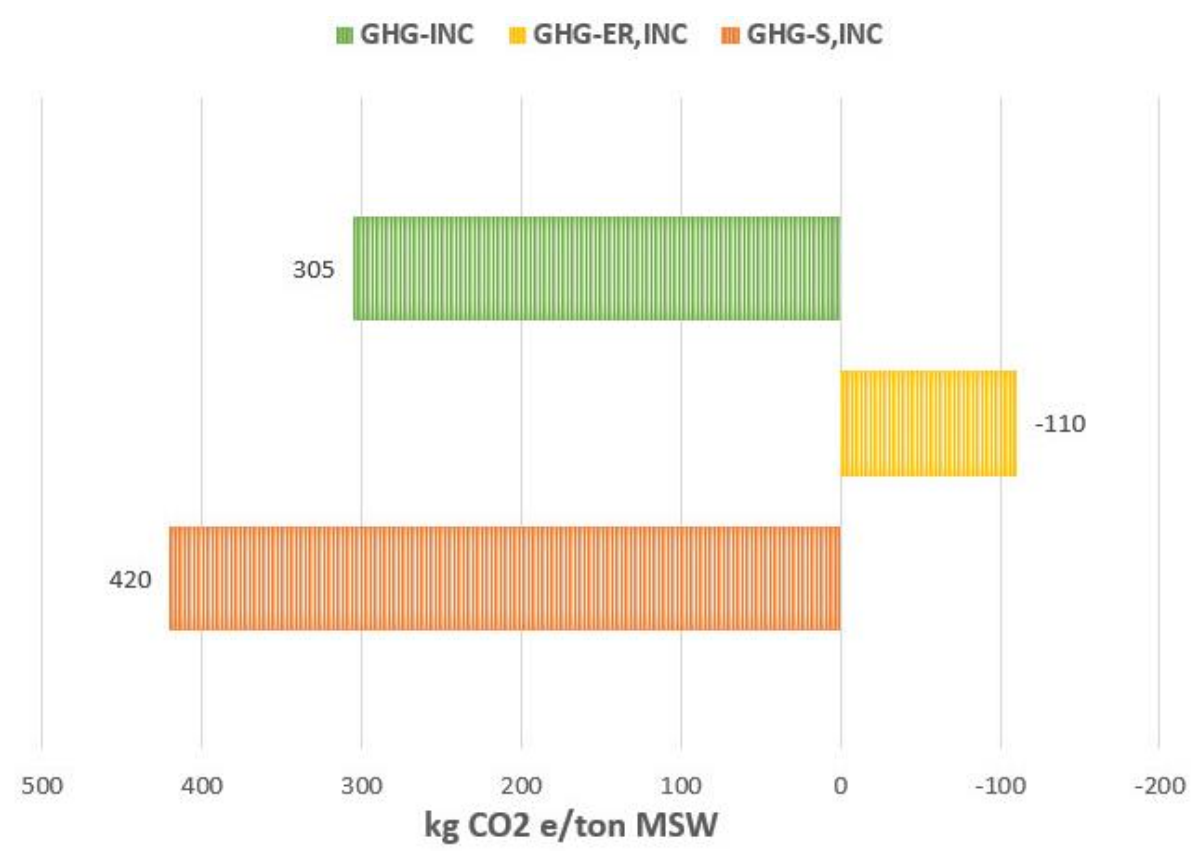

Figure 8. GHG emissions from incineration system

A sensitive analysis is performed for both proposed systems, i.e., landfill and incineration systems; each system is analyzed in two methods: one method considers the system without any heat recovery, like a common landfill or incineration system, and, so, the only production of the system will be the electric power. The other method includes a combined heating and power landfill or incineration framework which generates the electric power and the steam/hot water simultaneously as the productions of the system. Figure 9 shows the effect of LFG mass flow rate, $\dot{m}_{3}$, on the energy and exergy efficiencies of the landfill system in both common (right hand Yaxis) and CHP (left hand Y-axis) methods. According to this figure, the effectiveness of the CHP landfill system (i.e., with heat recovery) is more than that of the landfill system without heat recovery because of generation of steam beside the primary production, electric power. Also, it can be perceived that the total energy efficiency of the common landfill system, $\eta_{\mathrm{If}, \mathrm{C}}$, declines when the LFG flow rate increases; it is because of increment of LFG flow rate more than increment of produced electric power by the G.T. On the other hand, the total energy efficiency of the CHP landfill system, $\eta_{\text {lf,CHP }}$, increases by LFG flow rate increasing due to the extra steam produced in the system as another production of CHP system. The trend for the exergy efficiency of each method of the landfill system is similar to the energy efficiency for them because of the definition of the exergy efficiency.

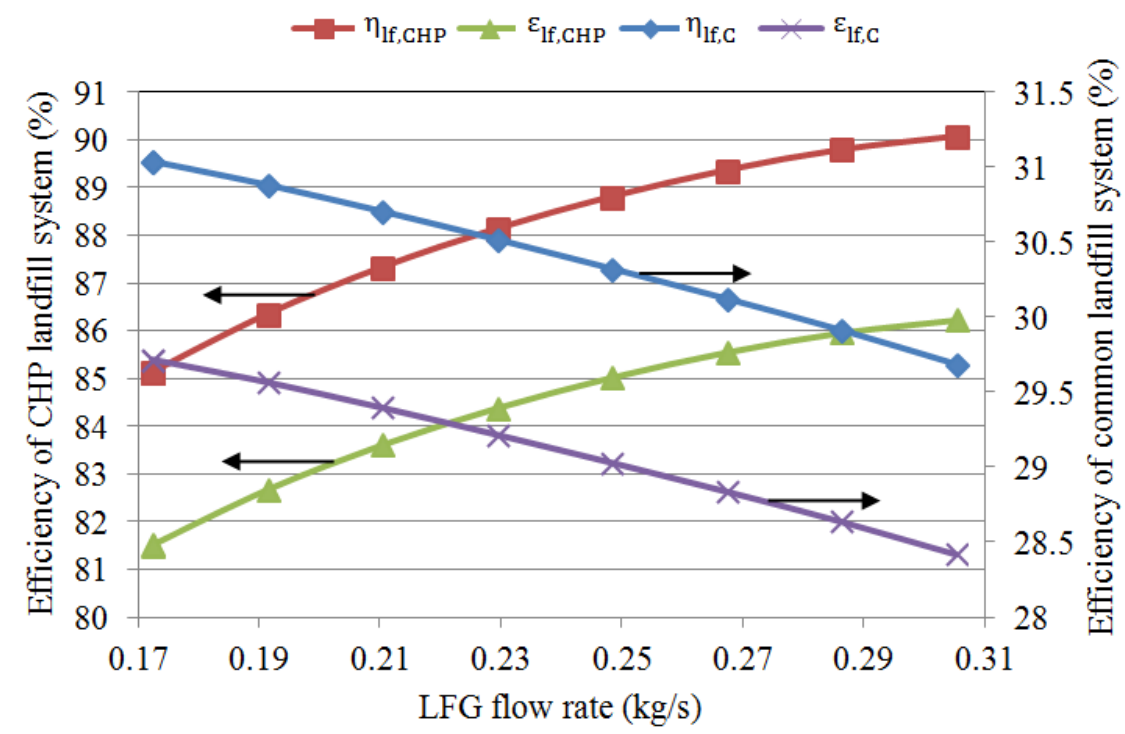

Figure 9. Effect of LFG flow rate on the energy and exergy efficiencies in common and CHP methods of the landfill system 
Figure 10 demonstrates the effect of the compressor pressure ratio (i.e., $\mathrm{P}_{2} / \mathrm{P}_{1}$ ) on the energy and exergy efficiencies of the landfill system in both conventional and CHP methods. As it has arisen from this figure, the total energy efficiency of the universal landfill system, $\eta_{\mathrm{If}, \mathrm{C}}$, has a maximum value in particular value of $\mathrm{P}_{2} / \mathrm{P}_{1}$ because of the compressor consumed power increment as its pressure ratio increases. The decrement of $\eta_{\mathrm{lf}, \mathrm{CHP}}$ with a compressor pressure ratio increase is due to the decrement of combustion products temperature and, so, the decrement of steam flow rate produced by the HRSG component. Considering the mentioned explanation for energy efficiency, the trend attained for exergy efficiency variation is expected according to the efficiency definition.

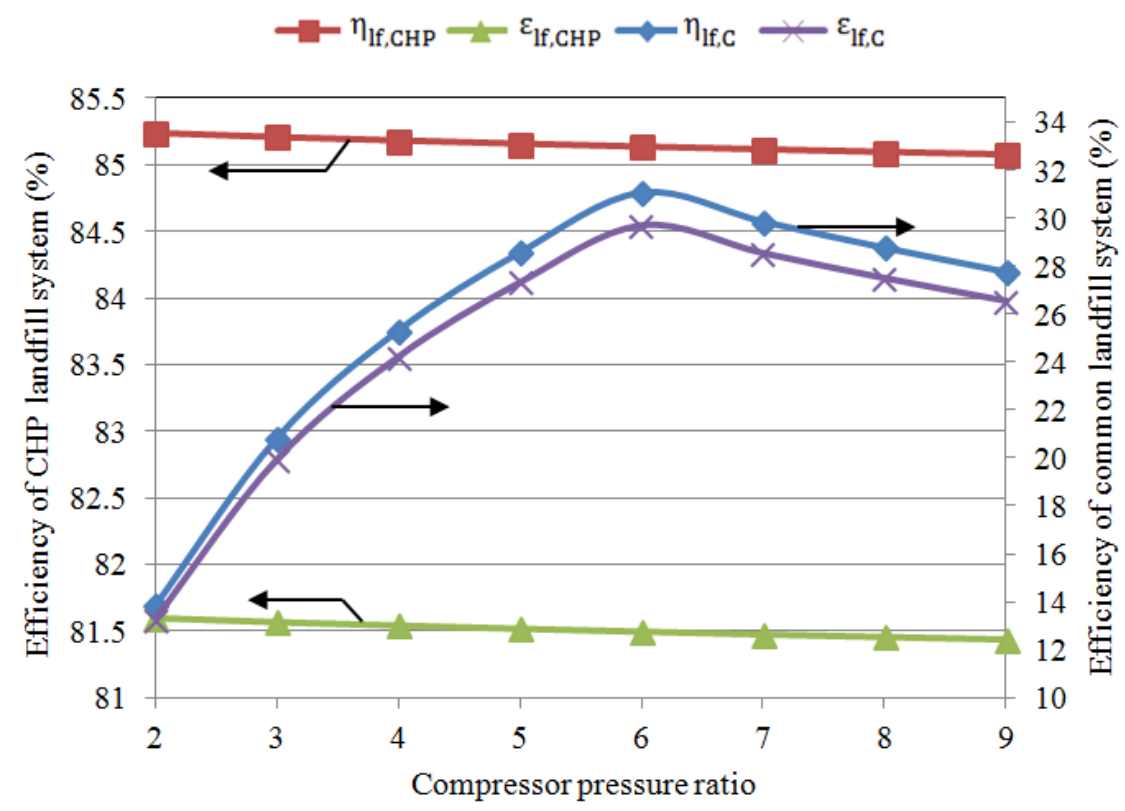

Figure 10. Effect of compressor pressure ratio on the energy and exergy efficiencies in common and CHP methods of the landfill system

The effects of inlet air flow rate, $\dot{m}_{1}$, on the energy and exergy efficiencies of the landfill system in both conventional and CHP methods are demonstrated by Figure 11 Based on this figure, as the combustion air flow rate increases, the energy and exergy efficiencies of the CHP landfill system decrease.

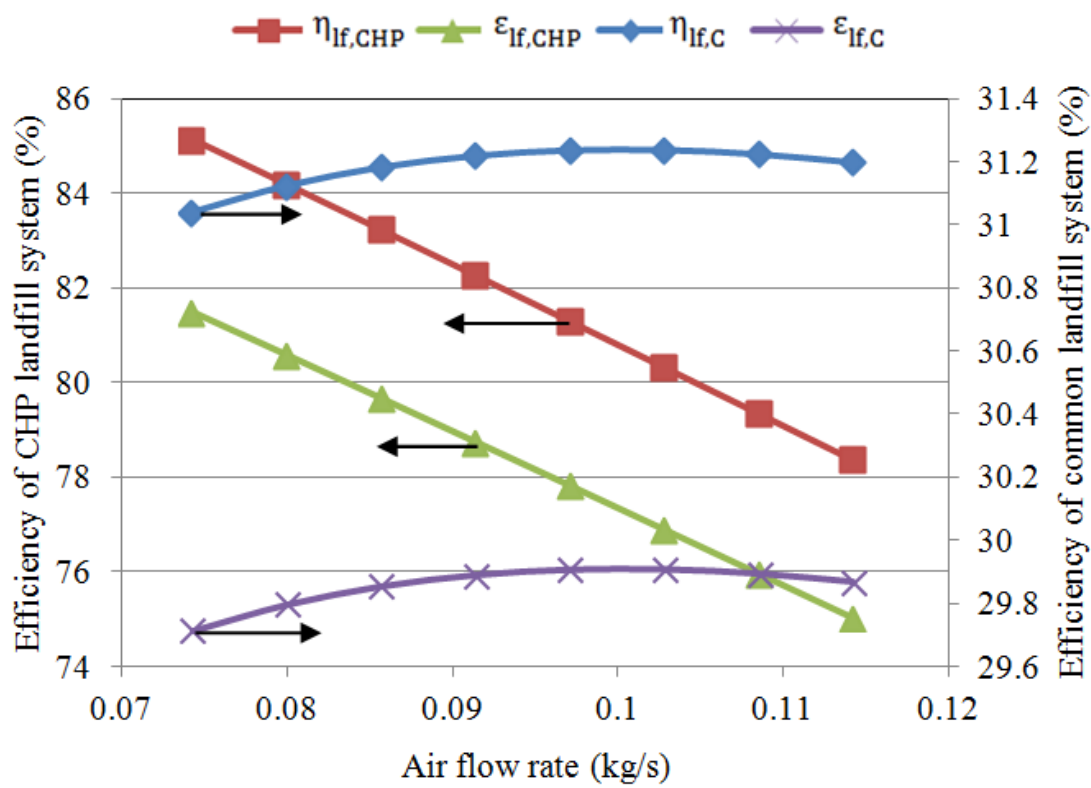

Figure 11. Effect of inlet air flow rate on the energy and exergy efficiencies in common and CHP methods of the landfill system 
Figure 12 indicates the effects of combustion products temperature, $\mathrm{T}_{4}$, on the energy and exergy efficiencies of the incineration system. According to this figure, as the combustion products temperature increases, the energy and exergy efficiencies of the cycle in both methods increase; the reason is the increment of the steam flow rate produced in the Blr and, so, the increment of power provided by S.T in the cycle.

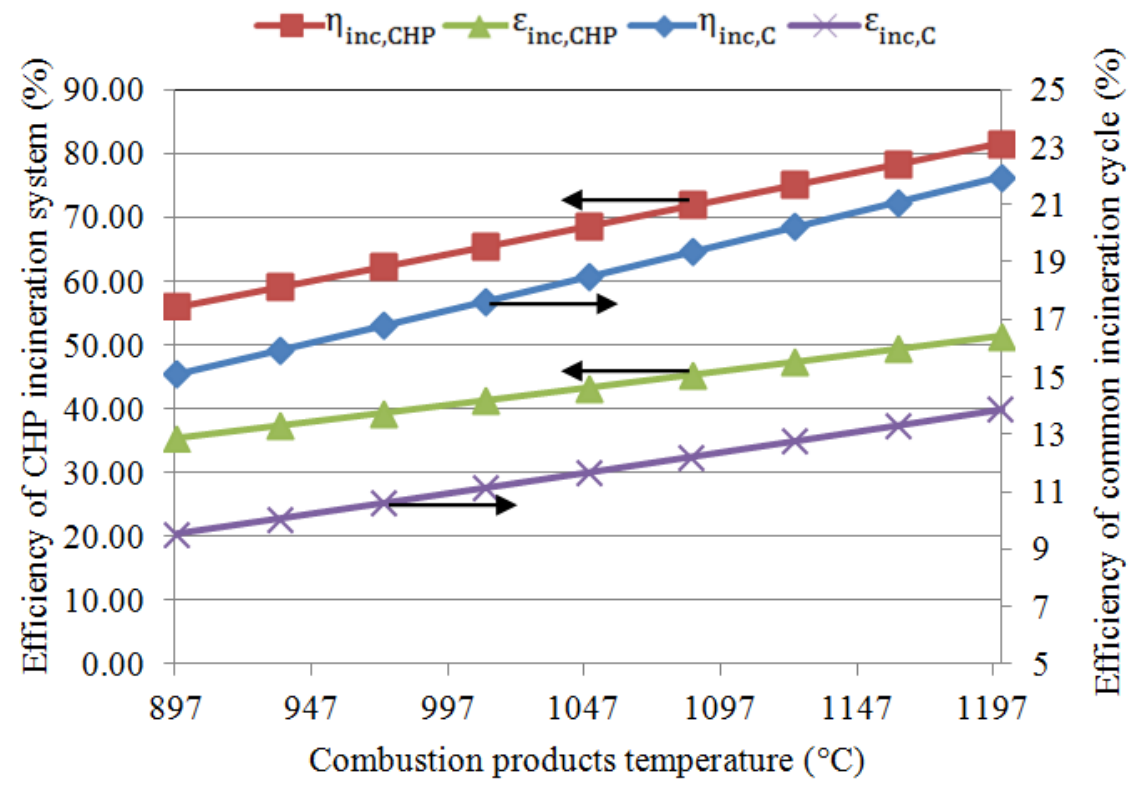

Figure 12. Effect of combustion products temperature on the energy and exergy efficiencies in common and CHP methods of the incineration system

The effect of steam turbine outlet pressure, $\mathrm{P}_{8}$, on the energy and exergy efficiencies of the incineration system is presented in Figure 13 for both considered methods. This figure shows that as the outlet pressure of the S.T increases, the effectiveness of the system decreases because of decrement of the power produced by the turbine.

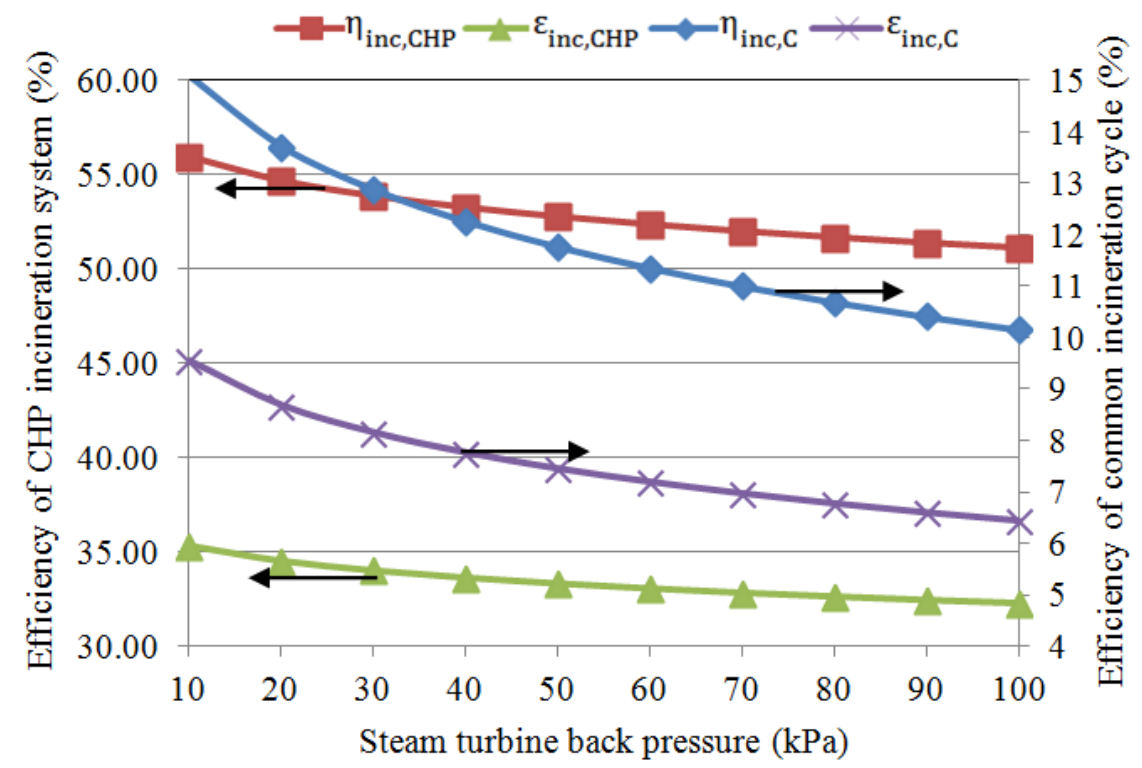

Figure 13. Effect of turbine back pressure on the energy and exergy efficiencies in common and CHP methods of the incineration system

As it is seen in Figure 14, the effect of steam turbine inlet pressure, $\mathrm{P}_{7}$, on the energy and exergy efficiencies of the incineration system in common and CHP methods is exhibited. An increase in S.T inlet pressure, based on Figure 14, increases system efficiency because of electric power generation increment in the turbine, as the primary production of incineration system in each method, as $\mathrm{P}_{7}$ increases. 
Journal of Thermal Engineering, Research Article, Vol. 6, No. 6, Special Issue 12, pp. 226-246, December, 2020

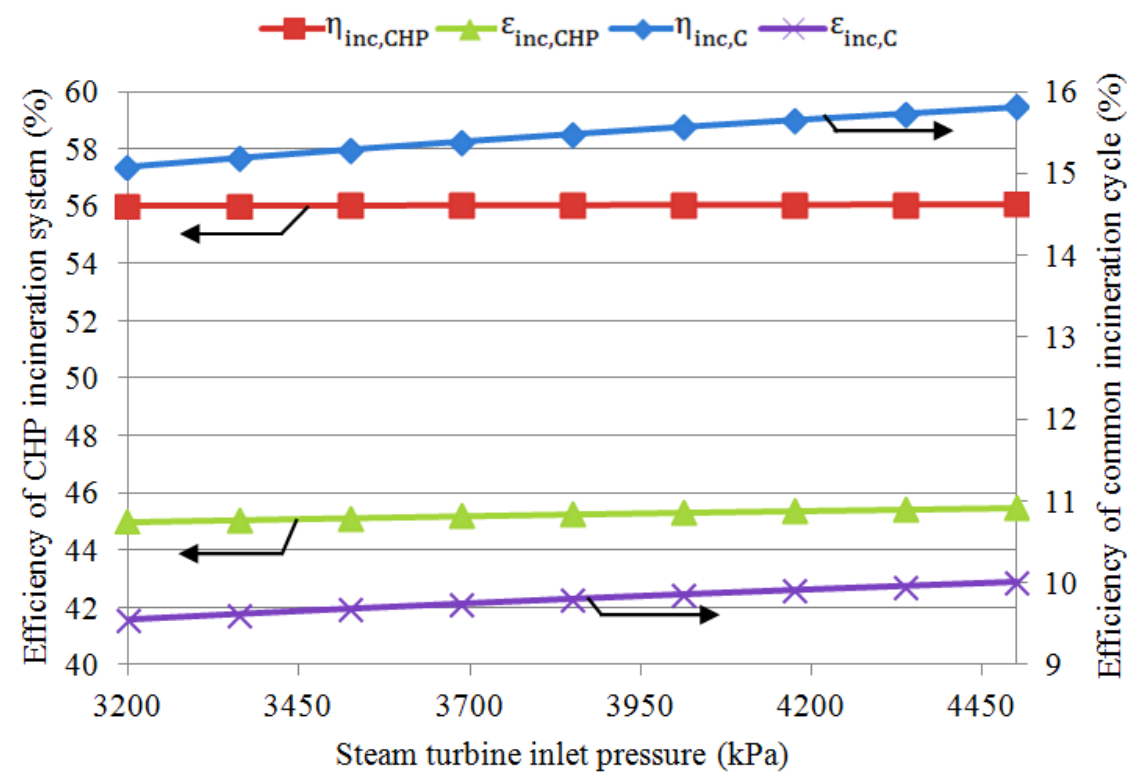

Figure 14. Effect of turbine inlet pressure on the energy and exergy efficiencies in common and CHP methods of the incineration system

Multi-Objective optimization is conducted for the landfill and incineration systems separately by using genetic algorithm programming in MATLAB. The decision variables and their variation range, which are used for the optimization purpose, are determined by sensitive analysis discussed in the previous section. The selected decision variables and their reasonable range for the landfill system are:

- Compressor pressure ratio, $\mathrm{P}_{\mathrm{cpr}}: 2 \leq \mathrm{P}_{\mathrm{cpr}} \leq 9$

- LFG mass flow rate, $\dot{m}_{3}: 0.172 \leq \dot{m}_{3} \leq 0.305$ (in kg/s)

- Air inlet flow rate, $\dot{m}_{1}:: 2.14 \leq \dot{m}_{1} \leq 3.30$ (in $\mathrm{kg} / \mathrm{s}$ )

Where, in fact, $\mathrm{P}_{\text {cpr }}$ : equals to $\mathrm{P}_{2} / \mathrm{P}_{1}$. Subsequently for the decision variables of the incineration system we have:

- Combustion products temperature, $\mathrm{T}_{4}: 897.85 \leq \mathrm{T}_{4} \leq 1200$ (in ${ }^{\circ} \mathrm{C}$ )

- Steam turbine outlet pressure, $\mathrm{P}_{8}: 10 \leq \mathrm{P}_{8} \leq 100$ (in $\mathrm{kPa}$ )

- Steam turbine inlet pressure, $\mathrm{P}_{7}: 3200 \leq \mathrm{P}_{7} \leq 4500$ (in $\mathrm{kPa}$ )

Considering the maximization of the energy and exergy efficiencies of the whole system as the objectives of optimization, the objective functions for the landfill system are expressed as follows:

$$
\text { Maximize } \boldsymbol{\eta}_{l f, C H P}\left(\dot{m}_{3}, P_{c p r}, \dot{m}_{1}\right)
$$

And

$$
\text { Maximize } \varepsilon_{l f, C H P}\left(\dot{m}_{3}, P_{c p r}, \dot{m}_{1}\right)
$$

Also, the objective functions for the incineration system are:

$$
\text { Maximize } \boldsymbol{\eta}_{\text {inc }, \mathrm{CHP}}\left(T_{4}, P_{8}, P_{7}\right)
$$

And

$$
\text { Maximize } \boldsymbol{\varepsilon}_{\text {inc }, \mathrm{CHP}}\left(T_{4}, P_{8}, P_{7}\right)
$$


By utilizing Genetic Algorithm considering 200 generations, with a looking for population size of 300 individuals, gene mutation probability of 0.5 , a crossover probability of 0.4 , a tournament size of 3 and a function set of: Times, Minus, Plus, separate and Exp as the GA parameters, the output of GA based on the mentioned decision variables for the landfill system is then observed as follows for the energy efficiency function:

$$
\eta_{l f, C H P}=276.5 \times\left(\dot{m}_{3}-\dot{m}_{1}\right)-\frac{3407 \times \dot{m}_{3}{ }^{3} \times\left(\dot{m}_{3}-P_{c p r}+\dot{m}_{1}\right)}{e^{\dot{m}_{1}} \times\left(2 \times \dot{m}_{3}-2 \times P_{c p r}+\dot{m}_{1}\right)}+57.7
$$

The maximum error between calculated and expected values in the above equation is $0.134 \%$. Also, the following expression is attained for the exergy efficiency function using 150 generations, search population size of 400 individuals, gene mutation probability of 0.35 , crossover probability of 0.35 and tournament size of 7 as the GA parameters:

$$
\begin{aligned}
& \varepsilon_{l f, C H P} \\
& =\left(891.8 \times \dot{m}_{1}-167.5 \times \dot{m}_{3}\right) \\
& \quad 167.5 \times\left(\left[\dot{m}_{1}-\dot{m}_{3}\right] \times \dot{m}_{1} \times\left(\left[\dot{m}_{3} \times \dot{m}_{1}\right]-\dot{m}_{1}+\frac{\dot{m}_{1}-\dot{m}_{1}^{2}}{\left(2 \times P_{c p r}\right)+\dot{m}_{1} / \dot{m}_{3}}\right)\right) \\
& -\frac{\dot{m}_{3}}{-\left(\left[891.8 \times \dot{m}_{3}\right] \times\left(\left[P_{c p r} \times \dot{m}_{1} \times \dot{m}_{3}{ }^{6}\right]+\dot{m}_{1}\right)+120.4\right)}
\end{aligned}
$$

The maximum error for the above equation is computed to be $0.225 \%$ approximately. Therefore, the final results of landfill system optimization are reported in Table 10.

Table 10. Comparison table between base case and optimum case of landfill system

\begin{tabular}{|c|c|c|}
\hline Parameters & Base case & Optimum case \\
\hline$\dot{m}_{1}(\mathrm{~kg} / \mathrm{s})$ & 2.14 & 2.14 \\
\hline$\dot{m}_{3}(\mathrm{~kg} / \mathrm{s})$ & 0.17 & 0.24 \\
\hline $\mathrm{P}_{\mathrm{cpr}}$ & 6 & 2 \\
\hline $\mathrm{P}_{\mathrm{Net}, \mathrm{If}}(\mathrm{kW})$ & 946 & 568.5 \\
\hline$\dot{m}_{\mathrm{S}, \mathrm{If}}(\mathrm{kg} / \mathrm{s})$ & 0.485 & 1.02 \\
\hline$\eta_{\mathrm{If,CHP}}(\%)$ & 76.77 & 82.15 \\
\hline$\varepsilon_{\mathrm{lf}, \mathrm{HPP}}(\%)$ & 73.47 & 78.27 \\
\hline
\end{tabular}

Based on this table, the final-optimal point performs a total energy efficiency of $82.15 \%$ and total exergy efficiency of $78.27 \%$ for the CHP landfill system. Table 10 also indicates the number of outputs of the system at the optimum point and the corresponding optimum thermodynamic parameters of the system (i.e., decision variables). As presented in this table, in the final optimum point which both energy and exergy efficiencies of the whole process are simultaneously in their possible maximum values, energy and exergy efficiencies improve by $7.01 \%$ and $6.53 \%$ respectively as compared to the non-optimized system. On the other hand, for the aim of incineration system optimization, considering Genetic Algorithm parameters as: 270 generations, with a search population size of 350 individuals, gene mutation probability of 0.4 , a crossover probability of 0.5 , a tournament size of 5 and a function set of: Times, Minus, Plus, Divide, Exp, Log, the output based on the mentioned decision variables for the energy efficiency function is attained as follows:

$$
\begin{aligned}
& \eta_{\text {inc }, C H P}=\left(0.0009788 \times T_{4}\right)-\left[0.1415 \times \log \left(3 \times T_{4}+2 \times P_{8}\right)\right. \\
& \quad+0.0009788 \times \log \left(4.154 \times P_{6}{ }^{2}-3.053\right)-0.01732 \times \log \left(P_{8}\right) \\
& \quad+0.8222]
\end{aligned}
$$


The maximum error achieved is about $0.009 \%$ that shows a good fitness for this function. Consequently, for the exergy efficiency function considering 200 generations, search population size of 300 individuals, gene mutation probability of 0.5 , crossover probability of 0.4 and tournament size of 6 , the following expression is attained:

$\varepsilon_{\text {inc }, C H P}$

$=\left(1.677 \times 10^{-7} \times T_{4} \times P_{6}\right)-1.368 \times 10^{-7} \times\left[\left(0.3898 \times P_{6}-16.3\right) \times\left(T_{4}-7.37\right)\right]$

$-\left(1.448 \times 10^{-7} \times T_{4} \times P_{8}\right)$

$-\frac{1.209 \times 10^{-10} \times\left(T_{4}-\left[T_{4} \times\left(1.013 \times T_{4}^{2}+T_{4} \times P_{6}\right)-\left(86.68 \times P_{6}+1.013 \times P_{8}\right)\right]\right)}{\left(P_{8}+0.04208\right)}$

$+\left(1.081 \times 10^{-6}\right)$

The maximum error for the above equation is then determined to be $3.586 \%$ approximately. The final optimization results of the incineration system are indicated in Table 11.

Table 11. Comparison table between base case and optimum case of incineration system

\begin{tabular}{|c|c|c|}
\hline Parameters & Base case & Optimum case \\
\hline $\mathrm{T}_{4}\left({ }^{\circ} \mathrm{C}\right)$ & 897.85 & 1200 \\
\hline $\mathrm{P}_{8}(\mathrm{kPa})$ & 10 & 10 \\
\hline $\mathrm{P}_{7}(\mathrm{kPa})$ & 3200 & 4500 \\
\hline $\mathrm{P}_{\mathrm{Net}, \mathrm{Inc}}(\mathrm{kW})$ & 1824 & 2785 \\
\hline$\dot{m}_{\mathrm{HW}, \mathrm{Inc}}(\mathrm{kg} / \mathrm{s})$ & 40 & 63 \\
\hline$\eta_{\mathrm{inc}, \mathrm{CHP}}(\%)$ & 55.96 & 81.34 \\
\hline$\varepsilon_{\text {inc,CHP }}(\%)$ & 35.86 & 69.12 \\
\hline
\end{tabular}

As vented in this table, for the CHP incineration system, the final-optimal point indicates the total energy efficiency of $81.34 \%$ and total exergy efficiency of $69.12 \%$. This table also presents the outputs of the optimized system and the corresponding thermodynamic parameters of the system. In the final optimum state, which both total energy and exergy efficiencies are simultaneously in the maximum values, they increase by $45.35 \%$ and $92.75 \%$ respectively compared to the base case.

\section{CONCLUSION}

In this paper, two WtE systems, a CHP landfill plant and a CHP incineration system, are investigated from the viewpoint of exergy and environmentally based on Varamin city data to determine the best order conclusively. For this purpose, energy and exergy performances and, also, total GHG emissions calculations are conducted using EES software. Then, the effects of key parameters as decision variables on the energy and exergy efficiencies are identified by sensitive analysis of both systems. Afterward, each system is optimized to thermal and exergy efficiencies maximization simultaneously employing a genetic algorithm method using MATLAB software. Several significant outcomes can be drawn from this study:

- In the landfill system, C.C and HRSG have the significant rule in annihilating the total exergy input to the system as they destruct $96 \%$ of total exergy fed to the cycle; so, improving the exergetic efficiency of these components is necessary. Preheating the combustion air by radiation zone of C.C and avoiding mismatched heat capacity rates of the two streams in the HRSG are proposals to improve the performance of these components. 
- The exergy annihilation ratio is the most for the French in the incineration framework among the other components. Reducing the air-fuel ratio and preheating the combustion air can decrease the irreversibilities of chemical reaction occurred in France and, so, improve the performance of the mentioned component.

- Environmental analysis based on GHG emissions shows that landfill system emitted less GHG than incineration system. Increment of recovery rate for LFG in landfill system and improvement of electricity and heat production and, so, energy and exergy efficiencies in both systems can reduce the GHG emissions.

- An increase in LFG flow rate of CHP landfill system causes an increase in the total energy and exergy efficiencies of the system. Also, as the combustion products temperature climb, the energy and exergy efficiencies of the CHP incineration system increase.

- The multi-objective optimization of the landfill system utilizing GA performs $7.01 \%$ and $6.53 \%$ improvement in total energy and exergy efficiencies respectively as compared to a non-optimized system. Additionally, the overall electric power produced is diminished by $39.90 \%$, and the steam production is extremely enhanced by $110.31 \%$ at the optimum conditions.

- For the incineration system, the multi-objective optimization using GA indicates a significant improvement of $45.35 \%$ and $92.75 \%$ in total energy and exergy efficiencies respectively as compared to the base system. Moreover, the net electric power and the hot water produced are improved by $52.69 \%$ and $57.50 \%$ at the optimal-point of the system.

- Finally, according to the lower GHG emissions and higher energy and exergy efficiencies achieved by landfill system, using the proposed CHP landfill plant is energetically and environmentally more appropriate than using the incineration plant for Varamin city.

\section{NOMENCLATURE}

Exergy efficiency (\%)

Energy efficiency (\%)

Specific enthalpy $(\mathrm{kJ} / \mathrm{kg}) / \mathrm{hour}$

Mass flow rate $(\mathrm{kg} / \mathrm{s})$

Heat rate $(\mathrm{kW})$

Gas constant $(\mathrm{kJ} / \mathrm{kg}-\mathrm{K})$

Specific entropy (kJ/kg-K)

Temperature $\left({ }^{\circ} \mathrm{C}\right.$ or $\left.\mathrm{K}\right)$

Exergy $(\mathrm{kW})$

Specific exergy $(\mathrm{kW} / \mathrm{kg})$

Mole fraction

Power (kW)

Giga

joule

Component/stream/kilo

\section{SUBSCRIPTS}

0

$1,2,3, \ldots$

D

F

Ambient/Dead state

Cycle locations

Destruction

Feed exergy 
Journal of Thermal Engineering, Research Article, Vol. 6, No. 6, Special Issue 12, pp. 226-246, December, 2020

\begin{tabular}{|c|c|}
\hline f & Fuel \\
\hline $\mathrm{i}$ & Inlet \\
\hline $\mathrm{j}$ & Component in mixture \\
\hline $\mathrm{k}$ & Component in cycle \\
\hline o & Outlet \\
\hline $\mathrm{P}$ & Product exergy \\
\hline Q & Boundary heat transferring \\
\hline $\mathrm{S}$ & Steam/Stack \\
\hline $\mathrm{W}$ & Boundary mechanical work \\
\hline $\mathrm{g}$ & Gram \\
\hline M & Mega \\
\hline \multicolumn{2}{|c|}{ ABBREVIATION } \\
\hline GHG & Greenhouse gas emission parameter ( $\mathrm{kg}$ of $\mathrm{CO}_{2} \mathrm{e} / \mathrm{ton}$ of $\left.\mathrm{MSW}\right)$ \\
\hline LHV & Low heating value parameter $(\mathrm{kJ} / \mathrm{kg})$ \\
\hline A.C & Air compressor \\
\hline Blr & Boiler \\
\hline C.C & Combustion chamber \\
\hline $\mathrm{CH}$ & Chemical \\
\hline CHP & Combined heating and power \\
\hline Cond & Condenser \\
\hline ER & Electricity \\
\hline Frnc & Furnace \\
\hline G.T & Gas turbine \\
\hline HRSG & Heat recovery steam generator \\
\hline HW & Hot water \\
\hline Inc & Incineration \\
\hline $\mathrm{Lf}$ & Landfill \\
\hline LFG & Landfill gas \\
\hline mthn & Methane \\
\hline $\mathrm{PH}$ & Physical \\
\hline S.T & Steam turbine \\
\hline SW & Solid waste \\
\hline Tot & total \\
\hline Net & Network \\
\hline EES & Engineering equation solver \\
\hline $\mathrm{KN}$ & Kinetic \\
\hline PT & Potential \\
\hline
\end{tabular}


Journal of Thermal Engineering, Research Article, Vol. 6, No. 6, Special Issue 12, pp. 226-246, December, 2020

\section{REFERENCES}

[1] Tumen Ozdil NF, Pekdur A. Energy and exergy assessment of a cogeneration system in food industry: A case study. Int J Exergy 2016. doi:10.1504/IJEX.2016.076866.

[2] Tumen Ozdil NF, Tantekin A, Erbay Z. Energy and exergy analyses of a fluidized bed coal combustor steam plant in textile industry. Fuel 2016. doi:10.1016/j.fuel.2016.06.091.

[3] Özdil NF, Tantekin A, Pekdur A. Performance assessment of a cogeneration system in food industry. J Therm Eng 2018. doi:10.18186/journal-of-thermal-engineering. 382412.

[4] Tantekin A, Özdil NF. Thermodynamic analysis of a fluidized bed coal combustor steam plant in textile industry. J Therm Eng 2017. doi:10.18186/journal-of-thermal-engineering. 353690.

[5] Tumen Ozdil NF, Tantekin A. Exergy and exergoeconomic assessments of an electricity production system in a running wastewater treatment plant. Renew Energy 2016. doi:10.1016/j.renene.2016.05.039.

[6] Ghaebi H, Abbaspour G. Performance analysis and thermodynamic modeling of a poly generation system by integrating a multi-effect-desalination thermo-vapor compression (MED-TVC) system with a combined cooling, heating and power (CCHP) system. J Therm Eng 2018. doi:10.18186/journal-ofthermal-engineering. 410264 .

[7] Thornley P, Upham P, Huang Y, Rezvani S, Brammer J, Rogers J. Integrated assessment of bioelectricity technology options. Energy Policy 2009. doi:10.1016/j.enpol.2008.10.032.

[8] Bove R, Lunghi P. Electric power generation from landfill gas using traditional and innovative technologies. Energy Convers Manag 2006. doi:10.1016/j.enconman.2005.08.017.

[9] Sun L, Fujii M, Tasaki T, Dong H, Ohnishi S. Improving waste to energy rate by promoting an integrated municipal solid-waste management system. Resour Conserv Recycl 2018. doi:10.1016/j.resconrec.2018.05.005.

[10] Xydis G, Nanaki E, Koroneos C. Exergy analysis of biogas production from a municipal solid waste landfill. Sustain Energy Technol Assessments 2013. doi:10.1016/j.seta.2013.08.003.

[11] Trindade AB, Carlos J, Palacio E, González AM, Rúa Orozco DJ, Silva Lora EE, et al. Advanced exergy analysis and environmental assesment of the steam cycle of an incineration system of municipal solid waste with energy recovery. Energy Convers Manag 2018.

[12] Azami S, Taheri M, Pourali O, Torabi F. Energy and exergy analyses of a mass-fired boiler for a proposed waste-to-energy power plant in Tehran. Appl Therm Eng 2018. doi:10.1016/j.applthermaleng.2018.05.045.

[13] Leckner B. Process aspects in combustion and gasification Waste-to-Energy (WtE) units. Waste Manag 2015. doi:10.1016/j.wasman.2014.04.019.

[14] Lombardi L, Carnevale E, Corti A. A review of technologies and performances of thermal treatment systems for energy recovery from waste. Waste Manag 2015. doi:10.1016/j.wasman.2014.11.010.

[15] Hong J, Li X, Zhaojie C. Life cycle assessment of four municipal solid waste management scenarios in China. Waste Manag 2010. doi:10.1016/j.wasman.2010.03.038.

[16] Damgaard A, Riber C, Fruergaard T, Hulgaard T, Christensen TH. Life-cycle-assessment of the historical development of air pollution control and energy recovery in waste incineration. Waste Manag 2010. doi:10.1016/j.wasman.2010.03.025.

[17] Hessami MA. Specific applications of bio/landfill gas produced from waste organic material. Renew Energy 1994. doi:10.1016/0960-1481(94)90099-X.

[18] Raj NT, Iniyan S, Goic R. A review of renewable energy based cogeneration technologies. Renew Sustain Energy Rev 2011. doi:10.1016/j.rser.2011.06.003.

[19] Murphy JD, McKeogh E. Technical, economic and environmental analysis of energy production from municipal solid waste. Renew Energy 2004. doi:10.1016/j.renene.2003.12.002.

[20] EES. Software n.d. http://www.fchart.com/ees/.

[21] Houck CR, Joines JA, Key MG. A Genetic Algorithm for Function Optimization: A Matlab Implementation. 1995.

[22] Smith JM. Introduction to chemical engineering thermodynamics. J Chem Educ 1950. 
doi:10.1021/ed027p584.3.

[23] Ghasemi A, Heidarnejad P, Noorpoor A. A novel solar-biomass based multi-generation energy system including water desalination and liquefaction of natural gas system: Thermodynamic and thermoeconomic optimization. J Clean Prod 2018. doi:10.1016/j.jclepro.2018.05.160.

[24] Kotas TJ. Exergy analysis of simple processes. Exergy Method Therm. Plant Anal., 1985. doi:10.1016/b978-0-408-01350-5.50011-8.

[25] Noorpoor A, Heidarnejad P, Hashemian N, Ghasemi A. A thermodynamic model for exergetic performance and optimization of a solar and biomass-fuelled multigeneration system. Energy Equip Syst 2016. doi:10.22059/ees.2016.23044.

[26] Dincer I, Rosen MA. Energy, environment and sustainable development. Appl. Energy, 1999. doi:10.1016/S0306-2619(99)00111-7.

[27] Seshadri K. Thermal design and optimization. vol. 21. 1996. doi:10.1016/s0360-5442(96)90000-6.

[28] Kaviri AG, Jaafar MNM, Lazim TM. Modeling and multi-objective exergy based optimization of a combined cycle power plant using a genetic algorithm. Energy Convers Manag 2012. doi:10.1016/j.enconman.2012.01.002.

[29] Baghernejad A, Yaghoubi M. Exergoeconomic analysis and optimization of an Integrated Solar Combined Cycle System (ISCCS) using genetic algorithm. Energy Convers Manag 2011. doi:10.1016/j.enconman.2010.12.019.

[30] Ghasemi A, Hashemian N, Noorpoor A, Heidarnejad P. Exergy based optimization of a biomass and solar fuelled cchp hybrid seawater desalination plant. J Therm Eng 2017. doi:10.18186/thermal.290251.

[31] Ameri M, Mokhtari H, Mostafavi Sani M. 4E analyses and multi-objective optimization of different fuels application for a large combined cycle power plant. Energy 2018. doi:10.1016/j.energy.2018.05.039.

[32] Golkar B, Naserabad SN, Soleimany F, Dodange M, Ghasemi A, Mokhtari H, et al. Determination of optimum hybrid cooling wet/dry parameters and control system in off design condition: Case study. Appl Therm Eng 2019;149:132-50. doi:10.1016/j.applthermaleng.2018.12.017.

[33] Cao Y, Nikafshan Rad H, Hamedi Jamali D, Hashemian N, Ghasemi A. A novel multi-objective spiral optimization algorithm for an innovative solar/biomass-based multi-generation energy system: $3 \mathrm{E}$ analyses, and optimization algorithms comparison. Energy Convers Manag 2020;219:112961. doi:10.1016/j.enconman.2020.112961.

[34] Woon KS, Lo IMC. Greenhouse gas accounting of the proposed landfill extension and advanced incineration facility for municipal solid waste management in Hong Kong. Sci Total Environ 2013. doi:10.1016/j.scitotenv.2013.04.061.

[35] Wanichpongpan W, Gheewala SH. Life cycle assessment as a decision support tool for landfill gas-to energy projects. J Clean Prod 2007. doi:10.1016/j.jclepro.2006.06.008.

[36] https://www.epa.gov/air-emissions-factors-and-quantification/emissions-estimation-tools/2017.08 2017.

[37] http://pasmandvaramin.ir/2017.08 2017. 